\author{
Economics Working Paper Series
}

\author{
2019/011
}

\title{
Firm Behavior and Pollution in Small Geographies
}

\author{
Dakshina G. De Silva, Robert P. McComb, Anita R. Schiller and \\ Aurelie Slechten
}

The Department of Economics

Lancaster University Management School

Lancaster LA1 4YX

UK

(C) Authors

All rights reserved. Short sections of text, not to exceed two paragraphs, may be quoted without explicit permission, provided that full acknowledgement is given. 


\title{
Firm Behavior and Pollution in Small Geographies*
}

\author{
Dakshina G. De Silva ${ }^{\dagger} \quad$ Robert P. McComb ${ }^{\ddagger} \quad$ Anita R. Schiller ${ }^{\S} \quad$ Aurelie Slechten
}

\begin{abstract}
We consider the relationship between the location choices of potentially polluting firms and local income. Unlike previous research in the area of economic justice, we distinguish between pollution potential and actual releases of toxic substances in the locality. We explore the relationship between profit maximizing behavior of potentially polluting firms in their choice of both location and expenditures to influence the likelihood of toxic releases and their expected financial costs. We proxy the expenditures on prudential behavior by observing the co-localization of waste remediation activities. Evidence supports the conclusion that firms behave rationally in managing risk of toxic release.
\end{abstract}

JEL Classification: Q2, L6, R1.

Keywords: EKC, Environmental Justice, Agglomeration, Entry and Exit.

${ }^{*}$ We thank George Deltas, James Hartigan, seminar audiences from INRA in Montpellier and Iowa State University and participants at the 2018 Asian Meeting of the Econometric Society for comments and suggestions. We would also like to thank the Texas Workforce Commission for providing us with fully disclosed Quarterly Census of Employment and Wages data at the establishment level.

${ }^{\dagger}$ Department of Economics, Lancaster University Management School, Lancaster University, Lancaster, LA1 4YX, UK (e-mail: d.desilva@lancaster.ac.uk).

${ }^{\ddagger}$ Department of Economics, Texas Tech University, MS: 41014, Lubbock, TX 79409-1014, (e-mail: robert.mccomb@ttu.edu).

$\S$ Department of Economics, Lancaster University Management School, Lancaster University, Lancaster, LA1 4YX, UK (e-mail: anita.schiller@lancaster.ac.uk).

『Department of Economics, Lancaster University Management School, Lancaster University, Lancaster, LA1 4YX, UK (e-mail: a.slechten@lancaster.ac.uk). 


\section{Introduction}

Analysis of industrial localization and concentration has been of considerable interest since, at least, Marshall in 1920 and spawned a broad literature. However, there is a narrower question of whether the localization and distribution of polluting activities in the production of tradeables is the result of firms' strategic decisions based on local demographic characteristics. This more nuanced question falls within the strand of literature in the realm of environmental justice as well as the broader context of industrial organization.

From the perspective of environmental justice, the question is, "Are low income areas or areas with larger fractions of minorities disproportionately affected by potential health risk associated with exposure to toxic releases (Hamilton, 1995; Levinson,1996; Wolverton, 2009)?" A concomitant question is then, "Are polluting firms more likely to locate in lower income or higher minority areas?" On the other hand, there is the alternative question as to whether or not households self-select locally or regionally by income due, in part, to a correlation between housing prices and local environmental quality? If so, the correlation is ex post. Or, is there some combination of these circumstances at work to create the circumstances the literature reports?

This paper primarily analyzes the first question while showing that this effect is not the result of changes in demographic characteristics. Much of the literature has focused on actual or observed localized toxic releases and the demographic characteristics of the surrounding areas. In our view, the issue has two dimensions. The first dimension is whether demographic characteristics - in particular, income - of the local area influences potentially polluting firms' location choices. Then, importantly, we consider the second dimension as to whether the potentially polluting firms' choices on prudential expenditures that result in different likelihoods of toxic release are influenced by local demographic characteristics. That is, even though the previous literature has found correlation between toxic releases and lower income levels in the surrounding areas, it does not necessarily mean that potentially

polluting firms are more likely to locate in lower income areas, but rather that potentially firms in those lower income areas are more likely to realize that pollution potential because they take fewer costly precautions. 
Therefore, in this paper, we take a different approach, one that has the potential to add a critical understanding of location decisions of potentially polluting firms and their decisions that influence the likelihood of toxic releases. That is, we don't restrict the analysis to reported toxic releases, but we consider the universe of firms in industries that are represented in the Toxic Release Inventory, the potentially polluting firms, ${ }^{1}$ and analyze the demographic characteristics of the local area in the areas where these firms are located or locate.

To clarify the relationship between the location and toxic waste management choices of potentially polluting firms and local income levels, we first provide a theoretical framework. A potentially polluting firm seeking to maximize profits will be concerned about the liability of toxic releases and the threat such releases pose to its financial results. It will therefore take the residential characteristics of a location into account when valuing the legal costs and compensation it will have to pay in the event of a toxic release (Coase, 1960) and balance these costs with the costs of influencing the likelihood of toxic release through waste management services. Compensation for damages will of course increase as local property values and incomes are higher. Moreover, in the event of a toxic release, the probability of collective action by residents and other businesses may be higher. As proposed by Olson (1965), the expected benefits/awards of such actions are directly related to local income levels.

The combination of these two factors leads to a negative relationship between firm-level pollution and local income, consistent with the environmental justice literature. As the firms' exposure to pollution-related financial risk increases, a prudential response is to manage that risk by employing more waste management and remediation services. Two otherwise identical firms, one in a high income neighborhood and the other in a low income neighborhood, would be expected to demand different levels of waste management and remediation services, positively correlated to the surrounding incomes.

Like any firm choosing a location, a firm engaged in a potentially polluting activity needs to

\footnotetext{
${ }^{1} \mathrm{~A}$ potentially polluting firm is defined as any firm, regardless of size or reporting requirements, in a NAICS code identified by the Environmental Protection Agency's Toxic Release Inventory (TRI), excluding NAICS 562 Hazardous Waste. However, only firms in these NAICS codes that employ at least 10 FTEs and exceed EPA threshold limits in terms of their processing or usage of designated hazardous or toxic chemicals are subject to mandatory reporting within the TRI (https://www.epa.gov/toxics-release-inventory-tri-program). The firms subject to mandatory reporting are denoted in this paper as TRI-reporting firms. TRI-reporting firms responsible for toxic releases that exceed TRI limits are identified and treated in this paper as TRI-polluters. So, TRI-polluters are a subset of TRI-reporting firms, and TRI-reporting firms are a subset of TRI-type (potentially polluting) firms.
} 
consider the array of attributes of any particular location in terms of their importance in profitability. ${ }^{2}$ A potentially polluting firm, however, must also consider the financial risk of release and the necessary costs of managing the likelihood of toxic release. Clearly, as suggested above, a toxic release in a location in an isolated or low-income area will pose less financial loss than would be the case for a firm located in a densely populated or high-income area. And, at the same time, labor costs and rents will be lower in lower-income areas. On the other hand, workforce availability, economic and social infrastructure are generally more attractive in densely populated areas. Firms seeking a high quality workforce or needing well-developed social and economic infrastructure will prefer higher income locations. So, there are, as always, trade-offs and the relationship between local income and the number of firms in a local area might be non-monotonic.

It seems reasonable to assume that the greater the number of potentially polluting firms, ceteris paribus, the greater the risk of pollution release. Recognizing that the incentives faced by a representative firm result in the realization of a localized aggregation of similar (potentially polluting) firms, we derive some conditions that can lead to either a positive or negative (or both) relationship between local income and the total level of potentially polluting activities in a neighborhood. We then investigate empirically the existence of these predictions of our theoretical framework by looking at the relationship between the location choices of potentially polluting firms, pollution hazards and local income levels. In this analysis, we consider the demand for remediation or waste management services as a demand that arises from firms concerned about the liability of toxic release in terms of their expected profits. Although not perfectly correlated with localized firms' demand for environmental quality, waste management/remediation is the only clearly identified industry involved in pollution mitigation in the regional non-tradeables sector for which entry and employment data are available.

By and large, the potentially polluting activities considered here result from industrial activity whose output is not dependent on the local market, i.e., production of tradeables. Firms in these activities are free to choose any location, subject to zoning restrictions. One might naturally think of household demand for localized environmental quality to be expressed collectively through the political

\footnotetext{
${ }^{2}$ Economists have long been interested in explaining what factors motivate profit-maximizing firms when the choose to open a new plant or expand an existing facility. There have been studies on the theory of plant location, including the role of taxes and agglomeration economies. Shadbegian and Wolverton (2012) review the theory, evidence, and implications of the role of environmental regulations in plant location decisions.
} 
process and reflected in a regulatory or statutory framework that restricts the nature, location and technologies of productive activities. By restricting our analysis to a single state, Texas, we control for an otherwise heterogenous regulatory framework. ${ }^{3}$ There are few local environmental restrictions imposed in the State of Texas, beyond local zoning laws, and the state itself takes a relatively light hand to regulation. Thus, jurisdictions in the state are largely subject to a practically identical regulatory environment. ${ }^{4}$ Differences in local demand for waste management services must arise from the consumers of those environmental services, i.e., local firms responding to localized conditions, and we largely eliminate any localized version of the pollution haven hypothesis due to regulatory heterogeneity.

One additional point needs to be made. Although residents might broadly express their preferences for environmental attributes through the political process, they can also express individual preferences for environmental attributes by moving across jurisdictions (in a Tiebout sense). Thus, a household that has a strong preference for low risk of toxic exposure would choose a locality in which there is little or no presence of potentially polluting activities. This would tend to put upward pressure on property values in the lower risk jurisdictions and to depress property values in the higher risk jurisdictions, assuming that few, if any, households would prefer a more exposed jurisdiction. This leads to reverse causality issues and this type of sorting would produce, through time, a negative simple correlation between the presence of polluting firms and median or average household income.

For this reason, in addition to the analysis of potentially polluting industry localization and household income, we consider the probability of entry of a potential polluter in and across the given geographies. By also focusing on entry, we avoid the question of inter-jurisdictional population sorting that might occur in the years following a potentially polluting firm's entry. Regional sorting by income due to the presence or absence of an environmental hazard, if it occurs, would already be

\footnotetext{
${ }^{3}$ Texas is an attractive setting to consider given its size. It is the second-largest state in the U.S. both geographically and economically (with a gross state product of $\$ 1.6$ trillion dollars in 2016). Its economy would rank 14th in the world when its gross state product is considered relative to national gross domestic products. It contains significant geo-physical diversity and is home to 25 separate MSAs.

${ }^{4}$ One example of the State's interference in local regulatory efforts was the widely reported lawsuit brought by the State against the City of Denton that banned hydraulic fracturing by referendum with $59 \%$ of the vote. The State sought to limit the municipality's ability to regulate oil and gas activities, to allow the State to pre-empt local regulations, and to ensure that all local efforts to impose regulations be "commercially reasonable." See the Texas Tribune, September 18, 2015 for reporting of the city's failure to block oil and gas activities.
} 
reflected in observed household incomes in the areas proximate or distant to the pre-existing industrial concentrations (demographic characteristics are given at the time of entry). Given the importance of waste management activities to generate a local Environmental Kuznets Curve (EKC) relationship, we conduct a separate but similar analysis of both localization and likelihood of entry of waste management/remediation firms into those geographies while controlling for the presence of TRI-type firms. In both cases, we control for agglomeration economies that might serve to attract firms into existing industrial concentrations (Glaeser et al., 1992; Henderson et al. 1995; Combes, 2000; Rosenthal and Stange, 2003).

Working at the census tract-level, we estimate the relationship between localization of potentially polluting firms (TRI-type firms) and a set of co-variates including local household income. We find that locations and entry probabilities of potentially polluting firms are positively correlated with local income over only the lower range of income and that these firms' demands for measures to reduce the likelihood of toxic release, as proxied by the presence and entry of waste management/remediation firms, show a similar, but amplified, pattern and are positively correlated with the presence of potentially polluting firms. We also find very persuasive evidence that the relative frequency of toxic release, i.e., the ratio of toxic releases to the number of potentially polluting firms, is negatively correlated with proximate household income.

The firm-level profit-maximization approach used in this paper has been common to economists investigating firm siting choices in relation to environmental issues. For example, List and Co (2000) used a conditional logit model to investigate in which states multinational firms make investments, leveraging variation in state environmental policies to consider whether foreign direct investment is, in part, driven by environmental standards. Likewise, List, McHone, and Millimet (2003) considered plant relocation choices made by firms, again finding differences in environmental factors (in this case, air quality regulations) significantly alter location choices. Turning to entry models, Keller and Levinson (2002) investigates the number of new foreign-owned plants as a function of abatement costs to determine the effect of environmental-related compliance costs on the location of foreign direct investments. In our paper, by restricting the analysis to a single state, Texas, we control for an otherwise heterogenous regulatory framework and focus on non-regulatory environmental factors and 
how these factors affect firms' siting and location choices.

Both our model's stylized facts and empirical estimation are consistent with a relationship similar to that expressed by the EKC. Our results lead us to conclude that the inverse U-shaped relationship between income and toxic release is, at least partially, the product of potentially polluting firms seeking to maximize expected profits in recognition of the financial risk associated with a toxic release. This empirical finding at small geographical scale is novel in the field of environmental economics and has clear application to both the literature on environmental justice and macro-scale economic analyses of the EKC.

We say this because the environmental justice literature has primarily focused on the relationship between local income and pollution exposure (Arora and Cason, 1999 and, Brooks and Sethi, 1997). While these papers find some empirical evidence of an EKC-type curve, the theoretical relationship between levels of undesirable localized emissions and regional or local income that would generate an inverted U-shaped curve or the role of the remediation industry have not been investigated. Hamilton (1995) and Wolverton (2009) find evidence that polluting firms choose to locate disproportionately in poor areas. However, in their analysis, they consider only firms in the Environmental Protection Agency's Toxic Release Inventory (TRI) which have actually reported a toxic release. While these results might well portray an effective reality, we find that limiting the analysis to TRI firms that have a release on record is overly narrow and may miss a useful, broader picture.

Polluting firms in the TRI are clearly only a subset of the larger universe of firms that can potentially have a toxic release. The question should not revolve around previous releases, assuming post-release remediation measures have been successful, but rather potential releases. Since similar firms in different household income localities may choose different levels of effort to limit releases, firms in lower income or less developed areas may simply be more likely to experience a release because the lower financial consequences of a release do not justify the cost of additional precautionary measures.

Second, with the seminal papers by Grossman and Krueger $(1993,1995)$ that introduced the construction of the EKC, there was considerable interest in examining the empirical relationship between environmental quality and income (Harbaugh et al., 2002; Stern, 2004). Many theoretical models have tried to offer consistent explanations of the EKC (de Bruyn and Heintz, 1999). However, these 
models typically use the representative agent or social welfare framework. They are, thus, focused on the demand side of the equation and not suitable for considering how firms approach production and pollution decisions.

The structure of the paper is as follows: in section 2, we present our theoretical framework and in section 3 we develop our empirical approach to study the existence of a local EKC-type relationship. In section 4 , we explain the patterns of entry and exit in the remediation industry. Section 5 lays out the conclusions.

\section{Theoretical analysis}

The question of residents' exposure to local pollution has two dimensions: (1) polluting firms location choices, and (2) their pollution level decisions. Local characteristics, including local income are likely to affect both the number of potentially-polluting firms in a locality and their efforts to avoid releases of hazardous waste in the environment. We develop a simple theoretical framework to illustrate under which conditions the combination of these two elements can lead to a negative or positive relationship between local pollution and income. We then use our theoretical structure to motivate our empirical analysis.

\subsection{Firm-level toxic releases}

From an individual polluter's perspective, releasing toxic chemicals in the environment is costly because the firm will have to implement a clean-up program, pay penalties and compensate the local residents for damages. ${ }^{5}$ Higher incomes (and associated higher property values) are expected to increase the costs of release in a local area (Hamilton, 1995) since, in litigation, injured parties recover damages based on reduced property values or, in the case of impacts that limit work or productive ability, lost income. Also, a higher-income area might be associated with a higher probability of collective actions by local residents to force the firm to implement a more thorough clean-up program in case of release.

To avoid legal and/or clean up costs associated with toxic releases, firms handling hazardous substances can undertake efforts to prevent these releases through costly waste management practices

\footnotetext{
${ }^{5}$ Indeed, most disposal or other release practices are subject to a variety of regulatory requirements designed to minimize potential harm to human health and the environment.
} 
such as treatment and recycling. ${ }^{6}$ Below we outline a simple framework to illustrate how firms balance these two types of costs.

A representative potentially polluting firm is located in area $l$, characterized by a median income $m_{l}$ and some other local characteristics $Z_{l}$. The production process generates or uses some hazardous substance $x$. Let $e_{l}$ be the amount of the hazardous substance that is released in the local area (posing a threat to the environment and human health) and $a_{l}=x-e_{l}$ be the amount that is treated or recycled. The cost of release is $e_{l} h\left(m_{l}\right)$, where $h\left(m_{l}\right)$ is the firm unit cost of release (e.g. cost of ex post remediation per unit of pollutant and/or compensation paid to local residents per unit of pollutant). As suggested above, $h^{\prime}\left(m_{l}\right)>0 .{ }^{7}$ Avoidance activities don't cause any damage but have an increasing and convex cost $p\left(a_{l}\right)$ (with $p(0)=0, p^{\prime}\left(a_{l}\right)>0$ and $p^{\prime \prime}\left(a_{l}\right)>0$ for all $\left.0 \leq a_{l} \leq x\right)$. The total pollution cost can then be written as:

$$
c_{l}\left(e_{l}, m_{l}\right)=e_{l} h\left(m_{l}\right)+p\left(x-e_{l}\right)
$$

Conditional on the decision to locate a new plant in area $l$, a firm will choose a level of releases, $e_{l}^{*}=\underset{e_{l}}{\arg \min } c_{l}\left(e_{l}, m_{l}\right){ }^{8}$ An interior solution $e_{l}^{*}>0$ will be given by:

$$
h\left(m_{l}\right)=p^{\prime}\left(x-e_{l}^{*}\right)
$$

The optimal pollution cost $c_{l}\left(e_{l}^{*}, m_{l}\right)=c_{l}^{*}$ is increasing in income, such that higher income areas imply higher costs of pollution. We can also show that firms tend to reduce their releases (and so increase their expenditures on waste management practices) in higher income locations:

$$
\frac{d e_{l}^{*}}{d m_{l}}=-\frac{x h^{\prime}\left(m_{l}\right)}{p^{\prime \prime}\left(x-e_{l}^{*}\right)}<0
$$

\footnotetext{
${ }^{6}$ Avoiding toxic releases can be done either ex ante (through pollution prevention activities, referred as $\mathrm{P} 2$ activities) or ex post (through waste management practices that prevent releases once hazardous wastes have been generated during the production process). However, previous studies (Harrington, 2012, 2013; Khanna et al 2009; Florida and Davison, 2001) show that local community characteristics, such as local income, have limited impact on P2 activities. Moreover, the effectiveness of P2 activities in achieving environmental targets or reducing pollution has shown to be limited only to some toxic chemicals and some industries (Sam, 2010; Gamper-Rabindran, 2006). This is why we focus on waste management practices and we implicitly assume that the total amount of waste generated by the production process does not depend on local income.

${ }^{7}$ We also assume that $h(0)=\underline{h}$, where $\underline{h}$ is a basic, obligatory clean-up program that must be undertaken by firms, in case of toxic release, regardless of citizens demand for or willingness to pay for a better environment.

${ }^{8} \mathrm{As} p^{\prime \prime}\left(a_{l}\right)>0$, the first-order condition is sufficient for a minimum. Moreover, there will be an interior solution to this problem if $p^{\prime}(0)<h\left(m_{l}\right)<p^{\prime}(x)$.
} 
Consistent with the environmental justice literature, lower income areas will be disproportionately subject to localized releases, although not necessarily more densely populated by TRI-type firms. Note that the rate at which firm's releases decrease with income will depend on the unit cost $h\left(m_{l}\right)$. In particular, if the unit cost of release is convex in income, the optimal amount of releases at the firm-level, $e_{l}^{*}$ will be decreasing and concave in income. ${ }^{9}$

\section{$2.2 \quad$ Number of firms}

In a profit-maximization framework (Levinson, 1996; Wolverton, 2009), a potentially-polluting firm considering the location of a new plant will choose the neighborhood with the attributes $\left(m_{l}, Z_{l}\right)$ that lead to the highest expected profit. A firm's expected profit in a local area $l$ is given by:

$$
\widehat{\pi}_{l}=F\left(w_{l}, y_{l}, c_{l}^{*}, v_{l}\right)
$$

where $w_{l}$ is a vector of local input prices, $y_{l}$ is a vector of local fixed factors (e.g. land, labor), $c_{l}^{*}$ is the optimal pollution cost derived in the previous section, and $v_{l}$ is a vector of other local factors that might affect the expected profits (e.g. minority ratio, residents' propensity to engage in collective actions...).

Intuitively, the higher the expected profit in a local area, the larger the number of firms located in this area. As local attributes $\left(m_{l}, Z_{l}\right)$ (including existing agglomeration economies) affect the arguments of $\widehat{\pi}_{l}$, the geographic distribution of firms/industries will depend on these local characteristics that drove their initial location decisions. Thus, we can write the equilibrium number of potentiallypolluting firms in local area $l$ as (ignoring the integer constraint on the number of firms for expositional purposes):

$$
N_{l}^{*}=N\left(m_{l}, Z_{l}\right)
$$

One reason why expected profit, and so the number of firms, might be negatively affected by local income is as argued above. That is, a firm's pollution cost $c_{l}^{*}$ is increasing, ceteris paribus, in local income. There are of course a number of other channels through which local income may affect potential

${ }^{9}$ Indeed, $\frac{d^{2} e_{l}^{*}}{d m_{l}^{2}}=-\frac{x h^{\prime \prime}\left(m_{l}\right)}{p^{\prime \prime}\left(x-e_{l}^{*}\right)}<0$ (if $p\left(a_{l}\right)$ is a quadratic function). 
profits. For example, more cohesive and effective collective action in wealthier areas (Olson, 1965) may act as a deterrent to certain firms considering a given location. Some neighborhoods/communities may lobby the local government to adopt stricter environmental standards above any broader regulatory requirements (see Fishel, 2005). Their ability to do so (included in the vector $v_{l}$ ) will depend on their income and willingness to bear the costs of the effort to achieve a cleaner environment. Moreover, higher income areas will be characterized by higher rental costs $\left(w_{l}\right)$, which may reduce the potential profit and the attractiveness of the locality.

Nevertheless, there are, as noted above, some offsetting benefits available in higher income areas that might attract and retain firms. Although wage rates may be higher, higher wage rates reflect higher marginal products of labor (quality of workforce) and, in the case of firms that require high skill labor inputs, reflect the availability of a workforce that matches their hiring needs $\left(y_{l}\right)$. Moreover, even if firms employ workers from other areas, higher income neighborhoods tend to have better physical and social infrastructure. This may contribute to lower logistical costs and help to retain workers or to attract workers from these other areas. Taken together, the elements outlined above suggest that the relationship between the number of firms and local income is difficult to predict on a purely theoretical level. That is, this relationship may be complex and non-monotonic.

\subsection{Local pollution and income}

We now investigate the relationship between total pollution in area $l, N_{l}^{*} e_{l}^{*}$, and local income $m_{l}$. It will depend on how the functions $N_{l}^{*}$ and $e_{l}^{*}$ vary with income (i.e. expressions (1) and (2).

First, note that, if the number of firms in a given location is decreasing in local income (i.e. firms always prefer to locate in low-income areas), total pollution will be decreasing, ceteris paribus, for all levels of local income, as predicted by the environmental justice literature.

However, it is very likely that for relatively low levels of income, the benefits of locating in an area with better quality workforce and physical infrastructure can outweigh the higher costs of land or pollution such that the equilibrium number firms in a local area is increasing with the local income. If that is the case and if for some income levels, the increase in the number of firms more than offsets the reduction in individual releases, then total pollution will be increasing for those income levels. Let 
$\varepsilon_{N, m}=\frac{d N_{l}^{*} / N_{l}^{*}}{d m_{l} / m_{l}}$ and $\varepsilon_{e, m}=\frac{d e_{l}^{*} / e_{l}^{*}}{d m_{l} / m_{l}}$ be the elasticities of $N_{l}^{*}$ and $e_{l}^{*}$ with respect to local income. An increase in the number of firms will more than offset the reduction in individual releases if $\varepsilon_{N, m}>\left|\varepsilon_{e, m}\right|$. We summarize these results in the following proposition:

Proposition 1. Total pollution in area $l$ is increasing in local income $m_{l}$ if there exist $0<\underline{m}<\bar{m}$ such that

1. $\frac{d N_{l}^{*}}{d m_{l}}>0$ for all $m_{l} \in[\underline{m}, \bar{m}]$, and

2. $\frac{\varepsilon_{N, m}}{\left|\varepsilon_{e, m}\right|}>1$ for all $m_{l} \in[\underline{m}, \bar{m}]$

Otherwise, total pollution in area $l$ is decreasing in local income.

\section{Empirical analysis}

We now turn to the empirical analysis of the relationship between local income, industrial localization and local environmental quality. For our purposes, a local area is the census tract. Census tracts in populous areas are relatively small. Thus, it represents the locality closely adjacent to any potentially polluting firm located in the tract. It also closely represents the population that bears the immediate environmental impact in case of toxic release. As previously noted, the analysis is limited to the State of Texas. Aside from the benefit of a homogeneous regulatory environment, we also are able to take advantage of access to detailed establishment-level data from the Texas Quarterly Census of Employment and Wages, as described below. Recognizing that the data are at the establishment level, we use the more usual terminology of the firm to indicate a specific productive facility.

\section{$3.1 \quad$ TRI data}

The Toxic Release Inventory (TRI) is a mandatory reporting program managed by the U.S. Environmental Protection Agency for a set of industries that use or produce certain toxic or dangerous chemicals. The EPCRA (Emergency Planning and Community Right to Know Act) Section 313 requires TRI reports to be filed by owners and operators of facilities that meet all of the following criteria:

- The facility has 10 or more full-time employee equivalents (FTE); 
- The facility is included in a given subset of the North American Industry Classification System (NAICS); and

- The facility manufactures (defined to include importing), processes, or otherwise uses any EPCRA Section 313 chemical in quantities greater than the established threshold in the course of a calendar year. ${ }^{10}$

As pointed out in Footnote 1, we define three sets of TRI-related firms. We refer to all firms located in a NAICS subject to TRI reporting, regardless of whether reporting is mandatory for the firm, as a TRI-type firm or potentially polluting firm but exclude firms in the NAICS 562 Waste Management and Remediation Services (this sub-sector group includes establishments engaged in the collection, treatment, and disposal of hazardous waste materials, see details below). There are 100,180 unique UI account numbers corresponding to this category of firms. Within the category of TRI-type firms are the firms for whom reporting is mandatory. Firms for whom reporting is mandatory are called TRI-reporting firms, a subset of TRI-type firms. TRI-reporting firms are not necessarily firms that experienced a toxic release. We cannot identify these firms directly from TRI data, but we can identify firms in the dataset that are located in NAICS codes for which reporting is mandatory and which have 10 or more FTEs. There are 32,441 firms thus identified as TRI-reporting firms. Firms that actually report toxic chemical releases are treated as a TRI-polluters for the year in which the release is reported. As such, a firm can be a polluter in year $t$, but not a polluter in year $t+i$. There are 795 unique firms that report a release over the period of this analysis. All other industries are treated as either non-TRI-type industries (i.e. they don't handle any toxic substance listed in the TRI Program) or remediation industries (NAICS 562). Lastly, there are 509,785 unique non-TRI-type, on remediation firms in the dataset.

The EPA also provides toxicity weights for each toxic chemical listed in the TRI Program which allows us to compute a tract-level toxicity index by aggregating all TRI-polluters' releases, measured in pounds of toxicity, within a tract. In our analysis, we only study the current-year's level of toxic releases because most TRI chemicals don't accumulate in the environment. Even though this index

\footnotetext{
${ }^{10}$ See https://www.epa.gov/toxics-release-inventory-tri-program for details on on NAICS codes, listed chemicals, and chemical thresholds required for reporting.
} 
only takes into account toxic releases from TRI polluters, we believe it constitutes a good proxy for the level of pollution in a local area. A firm may not report to the TRI Program for several reasons: it may not have had 10 or more full-time employees, its releases may have fallen below the reporting threshold or it may have failed to report. Therefore, total toxicity may exceed the reported number. While some papers (de Marchi and Hamilton (2006), and Koehler and Spengler (2007)) point to some underreporting, overall compliance was nevertheless high. Moreover, we believe it likely that releases by small firms probably represent a relatively small portion of total toxicity. This seems to indicate that the reason why TRI-type firms do not report is that their releases fall below the reporting threshold, so at levels the are not too damaging for the environment.

If firms don't report toxic releases, it might be because they successfully manage their hazardous wastes in different ways, e.g. treatment, recycling or disposal. This type of activity (even if the waste is treated on-site) is not carried out by the polluting firms because it requires an extensive and potentially costly government permitting process. Thus, they are usually carried out by specialized firms belonging to the remediation industry. The services supplied by these companies are local and often very specialized (depending on the type of polluting industry, pollutants, etc.) and typically require highly skilled/trained workers. Moreover, hazardous waste generated at a particular site often requires transport to an approved treatment, storage or disposal facility.

We restrict the waste management/remediation sector to four industry sub-sectors in NAICS 562 Waste Management and Remediation Services. Specifically, we consider establishments in NAICS 562112 Hazardous Waste Collection, 562211 Hazardous Waste Treatment and Disposal, 562910 Remediation Services, and 562920 Materials Recovery Facilities (recycling). We shall refer to these four NAICS codes collectively as either waste management or remediation industries (for our purposes, these two terms refer to the same set of industries).

\subsection{Firm-level data}

All firm and industry-level data are derived from the Texas Quarterly Census of Employment and Wages (QCEW) for the years 2000-2006 as provided by the Texas Workforce Commission. ${ }^{11}$ The

\footnotetext{
${ }^{11}$ The main data used in this study were collected and provided by the Texas Workforce Commission. These data are fully-disclosed (tax ID, locations, wages, and employment) and are not available to the general public. We were able
} 
QCEW reports data at the establishment level, including exact address, geographical coordinates, age, parent company, monthly employment, and quarterly payroll for all establishments in Texas subject to reporting under the Unemployment Insurance (UI) program. Different establishments within the same firm are identified by unique identification numbers and reported separately.

\subsection{Census-tract data}

Median income and population statistics at the census tract level are taken from the U.S. Census Bureau. For Census-based data, we linearly interpolate co-variates from Census 2000 and Census 2010 to generate yearly observations at the tract level. The realizations of the variables we use from Census 2000 and Census 2010 are of course highly correlated with each other. For example, the correlation between median income in 2000 and 2010 is 0.95 . A few Census 2000 tracts are divided in Census 2010. We aggregate variables (or construct population-weighted averages, where appropriate) to obtain corresponding Census 2000 tract information. We also consider some measures of local infrastructure (and, by that proxy, transportation costs) using the number of roads, number of rail roads, road construction expenditures.

Summary statistics are reported in Table $1 .{ }^{12}$ We observe that there are only 0.084 incumbent waste remediation firms per tract. For a representative tract, there are 4.018 TRI-type firms. Average median household income for the tracts is about $\$ 43,930$ and the average wage paid by establishments in each tract is about $\$ 38,250$ in the sample period. ${ }^{13}$ For a given tract, the average population is about 5,088 and the average unemployment rate is about 4.468 percent. The average house value is about $\$ 126,000$.

\footnotetext{
to acquire them under the terms of non-disclosure agreement. We can only provide the data under the terms of this agreement either in terms of establishment-level aggregation at the NAICS-6 or some industry aggregation of NAICS-6 establishment-level data at the county level. We can report total county-level data at NAICS-6 if there are at least four establishments in the county with no establishment representing more than $60 \%$ of the the total county employment in the given NAICS-6 industry. Interested researchers can contact the Texas Workforce Commission for data requests.

$12 \mathrm{~A}$ description of these variables is provided in Table A. 1.

${ }^{13}$ The median income refers to the residents of a particular tract, while wage refers to the wage paid by establishments located in this tract to their workers, who are not necessarily living in the same tract.
} 


\subsection{Testing for a relationship between localized pollution releases and area income}

We start our empirical analysis by investigating the relationship between local pollution and median income. Our measure of local pollution is the EPA toxicity index (in pounds) within a tract. As it will be shown in the next section, our data exhibit an EKC-type relationship between our measure of local pollution and median income. Using Proposition 1, we can derive some sufficient conditions for a local EKC. We will test empirically these conditions to investigate whether firms' location and pollution decisions are consistent with the observed pattern of local income and toxic releases:

1. $N_{l}^{*}$ is concave in income, with $\lim _{m_{l} \rightarrow 0} N_{l}^{*}=0$, and reaches a maximum at some income level $m_{l}=\widehat{m}>0$

2. $h\left(m_{l}\right)$ is convex in income, which implies that individual releases $e_{l}^{*}$ are decreasing and concave in income.

Condition 1 suggests that some areas are too undeveloped to attract industrial economic activity. Therefore, for relatively low levels of income, the benefits of locating in an area with better quality workforce and physical infrastructure can outweigh the higher costs of land or pollution such that the equilibrium number firms in a local area is increasing with the local income. Then, as local incomes increase and pollution, land and labor costs increase pari passu, the relationship between the number of industrial firms and income is likely to flatten out or even turn down as the costs tend to increase relative to the benefits.

Under condition 2, an increase in income will have a larger effect on the unit cost of releases, resulting in larger releases reduction for higher values of median income. Combining conditions 1 and 2 , we obtain that for relatively low income levels (where $N_{l}^{*}$ is very small), the increase in the number of firms in a location more than offsets the reduction in individual firm-level releases. Then, as income increases, $N_{l}^{*}$ flattens out while the effect of income on optimal releases increases. As a result, after some income level $m^{*}<\widehat{m}$ such that $\varepsilon_{N, m}=\left|\varepsilon_{e, m}\right|$, the increase in the number of firms will be offset by the reduction in individual firm-level releases. 
We will check the validity of the first condition in the empirical analysis by looking at the relationship between the total number of potentially polluting firms (TRI-type firms) and median income, controlling for the relevant additional factors.

Testable hypothesis 1: The number of TRI-type firms is increasing and concave in the tract median income up to some income level.

We check for the second condition in two different ways. First, we look at the relationship between income and property values (used as a proxy for unit cost of releases) in a given geography and our data show that the relationship is indeed convex (see Figure A1 in the Appendix). Second, we verify that individual releases are decreasing and concave in income by using the proportion of TRI-reporting firms that report a release in any given year relative to the set of potentially polluting firms, i.e., TRItype firms, and estimate how local characteristics, including local income, affect the relative frequency of TRI-polluters. ${ }^{14}$

Testable hypothesis 2: The relative frequency of TRI-polluters is decreasing and concave in the tract median income.

One of the basic premises of our theoretical framework is that in order to reduce their toxic releases firms spend more on waste management practices. As a proxy for waste management expenditures, we use the number of remediation firms per tract. Indeed, revenues of the remediation industry are for the most part reflected in costs of the local potentially polluting firms. This leads to our third hypothesis:

Testable hypothesis 3: Remediation firms will be more likely to locate in areas with larger numbers of TRI-type firms and in areas characterized by a higher median income.

\footnotetext{
${ }^{14}$ Note that in our data, we only observe toxic releases by firms reporting to the TRI Program and not for all the potential polluters. We use the number of TRI-polluters, not the number of toxic releases. A TRI-polluter could have more than one release per calendar year.
} 


\subsection{Results}

To test the predictions of the theoretical analysis, we estimate an empirical model that takes the following form:

$$
y_{l t}=X_{l t} \Delta+\tau_{t}+\mu_{l t}
$$

where $y$, depending on the specification, is total toxicity in pounds in each tract or the total number of firms in the TRI-type sector and in the remediation industry per tract at a given time. $X_{l}=(m, Z)_{l}^{\prime}$ is the tract- $l$ specific characteristics treated as median income $m$, average wage, college ratio, number of amenity-type establishments, infrastructure, population density, unemployment rate, land area, housing rental ratio, and housing prices in the year, $t$. Of these variables, median income is of particular interest in this analysis and we employ a cubic specification for income. Estimation results are reported in Table 2. ${ }^{15}$ The results for income are then graphed, ceteris paribus, in Figure 2. The familiar inverted U-shaped curve is present for the relationship between total toxicity and median income, peaking at median income of approximately $\$ 65,000$, as in De Silva, et al (2016). These results confirm the presence of an EKC-type relationship between local income and local pollution.

Of interest, the total numbers of firms in the TRI-type sectors in a tract increase and then level off at higher income levels, supporting our first testable hypothesis that the $\mathrm{EKC}$ is consistent with an increasing and concave number of firms. ${ }^{16}$ The number of firms in the waste remediation industry rise proportionately (slightly) slower than does the TRI-type sector over higher income levels, although they track closely for the most part, indicating that potentially-polluting firms in higher income tracts tend to utilize more remediation services. As one would expect from our third testable hypothesis, there is substantial correlation in Column 4 between the number of remediation firms and the number of TRI-type firms in each tract. These results indicate that, not surprisingly, remediation firms are more likely to locate in areas where a high number of potentially-polluting firms are present. In the next section, we investigate this result for remediation firms in more detail.

In Table 3, using the observed turning points in Figure 2, we re-estimate these relationships for

\footnotetext{
${ }^{15}$ De Silva et al. (2016) show that high polluting firms locate in high minority areas. As rent and income are correlated with race, we also estimate our models including the minority ratios. Our main findings remain consistent and these results are reported in Tables A2-A3 in Appendix.

${ }^{16}$ We also estimate the effect of local income on the total number of employees in a tract and the results are qualitatively the same as with the number of firms. These results are available upon request.
} 
the same set of correlates and the same three independent variables. However, in these estimations, we identify three intervals for median income in order to estimate linear splines, or piecewise linear relationships between the independent variables and median income. We find a positive relationship over the median income range $\$ 0-66,700$ for all three specifications, and a weakly significant negative relationship only for the highest range of median income with respect to toxicity. This reinforces the key observation in Figure 2 that a local EKC is consistent with a number of firms in waste remediation and TRI-type sectors that first increase with median income and then level off as median income levels increase beyond the threshold value.

Finally, we estimate the relative frequency of toxic releases (above the EPA threshold) reported to the TRI Program as a function of local income (testable hypothesis 2). Given the nature of our dependent variable, we estimate this fractional model using the method proposed by Papke and Wooldridge (1996). This is intended to capture the behavioral outcomes of TRI-type firms as a function of income. Results in Table 4 confirm that local income has a stronger impact on the relative frequency of toxic releases in higher-income tracts, indicating that the relative frequency of firm-level releases decreases at a lower rate for relatively low income levels than for higher income levels. This last result is consistent with the environmental justice literature; that is, firms' behavior toward the pollution risk, as well as localization, depends on local income.

\subsection{Robustness Checks}

\subsubsection{Self-sorting by TRI-type firms}

One concern might be that the result of a decreasing frequency of TRI polluters arises because of selfsorting by TRI-type firms. If those industries that have a higher likelihood of release tend to cluster in lower income areas, and those industries that have a lower likelihood of release are more likely to be found in higher income neighborhoods, then this result will emerge. To this point, we might note that this is not inconsistent with our hypotheses and results so far. Rather it would tend to reinforce the environmental justice argument. Nevertheless, we separated three industries at NAICS-3 for individual analysis. Our selection was based on the specific industries shares of all establishments in the TRI-type industries. We chose industries with a high, medium and low proportion of the complete 
set of TRI-type firms. Specifically, we chose chemicals, fabricated metal, and miscellaneous n.o.s. As reported in Table 5, the relative frequency of firms reporting toxic releases in both the chemicals and fabricated metal sectors retain a similar appearance to the relative frequency that appears for the TRI-type industries. The relative frequency of miscellaneous is not significantly related to income, perhaps because this industry is too sparsely present in the data

One other sorting issue may be that firms change locale to leave demographic conditions for a more suitable neighborhood in terms of financial risk associated with a release. During the course of the data, fewer than one-tenth of one percent of firms (90 TRI-type firms, of which 17 were TRI-reporting firms, out of a total of 100,180 TRI-type establishments) changed census tract. We do not find this issue to be important in this case.

\subsubsection{Causality}

A potential issue may be that our demographic variables are contemporaneous. Therefore, we reestimate these localization regressions with demographic characteristics lagged by a period. Our results are consistent and robust. However, we do not report these results in order to save space but we can provide them on request. Additionally, it may be the case that a tract's demographic characteristics (including income) change over time precisely because of firms' location decisions: residents express their preferences for environmental attributes by moving across jurisdictions. We deal with this endogeneity issue in different ways.

First, we look at the correlations between ranking of tracts in 2000 and 2006. These results are reported in Table A.6. Our results indicate that ranking of tracts based on income, education, and population are highly correlated between 2000 and 2006 and the correlation coefficient is more than 96 percent for all variables. To the extent that industrial concentrations in 2000 probably represent the cumulative effects of perhaps several decades, we might assume that sorting effects at the beginning or our sample period represent a population location equilibrium, or ex post sorting equilibrium.

Another way to deal with this reverse causality issue is to look at firms' entry models. Insofar as entrant's locational calculus is concerned, demographic characteristics of the potential localities are largely given. With this in mind, we utilize an entry model for TRI-type firms by focusing only on new 
entrants in our sample period (2000-2006). Controlling for other relevant factors, we should observe entrants' preferences with respect to local incomes without the issue of costly relocation that affects incumbent firms. Due to the large number of new entrants $(11,752)$, it is not possible to estimate this entry model using a conditional logit. Instead, we use the Poisson Pseudo Maximum Likelihood (PPML) method with time fixed effects. ${ }^{17}$ Compared to the standard Poisson estimation, the PPML the estimation does not assume that the data are distributed with the mean equal to the variance of the event count. The data need not even come from a Poisson process and may be either under or over-dispersed. However, note that the estimated coefficients are nevertheless identical to the Poisson regression estimates. All that is required for PPML consistency is that the conditional mean function be correctly specified. ${ }^{18}$ Here, the dependent variable is the number of TRI-type entrants $(y)$ for a given tract $(l)$ for a given year $(t)$. Tract-level independent variables are as described before. The basic model is as follows:

$$
E\left[y_{l t} \mid X_{l t}\right]=\exp \left(X_{l t}^{\prime} \psi+\tau_{t}\right)
$$

These entry results are presented in the Table 6 . We observe a clear correlation between TRI-type entrants and income (and other tract characteristics) as in our localization models. Although in this case, entrants have a clear preference for lower income tracts. This exercise is consistent with our theoretical prediction that local income drives firms' location decision behavior.

\subsubsection{MSA vs. Non-MSA}

Next we check whether our results are driven by non-MSA tracts and by TRI polluters. We reestimate our siting models where the dependent variable is the TRI type firms without reported polluters. That is, we define a category of TRI-type firms that contains only firms that have not reported a release. Further, we estimate these models for both MSA and non-MSA tracts separately. We present these results in Table A4 in the Appendix. Our findings indicate that results are not driven by pollutionreporting firms. Note also Column 4 that indicates that results for location choices of remediation

\footnotetext{
${ }^{17}$ In the same way, we could try to deal with the potential endogeneity between local income and toxicity index by estimating the effect of income on the number of TRI-polluter entrants. De Silva et al. (2016) use a PPML specification for TRI-polluters only and they find an EKC-type relationship with income. Currie et al. (2015) also use entry of TRI-polluters to evaluate the impact of toxic chemicals on infant health.

${ }^{18}$ For a more detailed discussion of this reasoning, see Gourieroux, Monfort, and Trognon (1984) and Santos Silva and Tenreyro $(2006,2011)$.
} 
firms are unaffected by the subtraction of TRI-polluters. The demand for waste management services seem to be driven by firms that do not report releases.

\subsubsection{Multiple establishments}

Additionally, one might be concerned that firms with multiple establishments may locate their manufacturing plant in a low income neighborhood while their sales office may be located in an affluent area. This does not seem to be the case in our sample as the average firm has only 1.3 branches. ${ }^{19}$

\subsubsection{Non-TRI-type firms}

It is natural to wonder if this inverted U-shaped relationship is not also observed in the case of nonTRI-type firms. That is, is this result specific to TRI-type firms or does industrial localization more generally exhibit this same pattern? To answer this question, we conducted a similar regression to analyze the localization of non-TRI-type firms. As can be seen in Table A.5, there is a positive relationship between income and localization of firms, ceteris paribus, over the two lower income splines and then the relationship flattens out (Column 1).

\section{$4 \quad$ Entry and exit patterns in the remediation industry}

In the previous section, we have shown that a local EKC-type relationship is consistent with an increasing number of TRI-type firms coupled with increasing expenditures of those firms in waste management activities. As mentioned above, this is our proxy for local demand for environmental quality. Waste remediation firms supply pollution risk management services in response to the demand for those services posed by potentially polluting firms. Given the importance of these activities to obtain the EKC-type relationship, we investigate further the structure of the industry supplying these remediation/waste management services.

\subsection{Entry}

In this section, we estimate the entry process of waste remediation establishments by census tract in Texas on an annual basis over the years 2000-2006. Establishment entry in any year is defined as

\footnotetext{
${ }^{19}$ This number is computed excluding industries as such as retail gasoline, commercial printing, and food processing which represent less than 5 percent of the sample. If we include these industries this number is about 2.6.
} 
the appearance (initial UI liability) of a new Enterprise Identification Number (EIN). We estimate the number of entrants in a particular location (tract) as a function of location characteristics. These characteristics include the number of remediation firms already present in that county (localization effects), the number of establishments in both TRI and non-TRI-related industries in that tract, median personal income, level of education attainment, amenities, infrastructure, population density, unemployment rate, and controls for housing ownership. We also include a dummy variable to control for tracts that are in counties bordering nearby states and Mexico. We present the distributions of incumbent and entrant firms for the waste remediation industry in Table 7.

The most common year of firm entry was 2002. This coincides with a TRI rule making which lowered reporting thresholds for lead and lead compounds. ${ }^{20}$ De Silva et al., (2016) show that, in 2002, the number of TRI reports involving lead or lead compounds increased six-fold compared to 2001. Also note that the aggregate announced toxic weight increased by a factor greater than four in 2002 relative to 2001. We argue that, with this threshold change, demand for waste remediation increased in 2002 and, hence, we see an uptick in entrants in 2002. There is an average of about 0.013 remediation entrants per tract over the entire period of the sample.

We empirically model a firm's $(i)$ location $(l$ - tract) choice of entry at time $t$ in order to maximize expected profits using a conditional Logit model (see McFadden, 1974). Each firm's after-entry profit from location $l, \pi_{i l t}$, can be written as follows:

$$
\pi_{i l t}=A_{l w t}^{\prime} \gamma+A_{l p t}^{\prime} \lambda+X_{l t}^{\prime} \beta+\tau_{t}+\epsilon_{i l t}
$$

$A_{l w t}$ is the number of incumbent waste remediation firms that are in a tract $l$ (which is a proxy for the total investment in prevention $e$ ). $A_{l p t}$ is the number of incumbent firms that are TRI-type in tract $l$, and $X_{l}$ is the tract $l$ specific characteristics, as mentioned above, in a given year, $t$. These two variables, $A_{l w t}$ and $A_{l p t}$, together capture the agglomeration effects in tract $l$. We assume that the disturbance, $\epsilon_{i l t}$, is independent and identically distributed.

In order to have a closed form expression for a firm's choice probabilities, we also assume that the $\epsilon_{i l t}$ are distributed with a Type 1 extreme value distribution. We further assume that each firm knows

\footnotetext{
${ }^{20}$ See Title 40, Part 372 of the Code of Federal Regulations which is summarized in volume 66 , number 11 of the Federal Register.
} 
its private costs and expected profits. This asymmetric information assumption enables us to convert the discrete actions of competitors into continuous location choice probabilities. Then, we can specify the conditional logit model as follows:

$$
\operatorname{Pr}\left(E_{i l t}=1 \mid A_{l w t}, A_{l p t}, X_{l t}, \tau_{t}\right)=\operatorname{Pr}\left(\pi_{i l t}>\pi_{i k t} \text { for all } l \neq k\right)
$$

The dependent variable $E_{i l t}$ equals 1 if a firm $i$ chooses location $l$ and 0 otherwise. A firm $i$ will choose location $l$ when $\pi_{i l}>\pi_{i k}$ for all $k \neq l$. Therefore, conditional on the decision to open a new plant, the probability that firm $i$ will choose a particular location $l$ can be written as follows:

$$
\operatorname{Pr}\left(E_{i l t}=1\right)=\frac{\exp \left(A_{l w t}^{\prime} \gamma+A_{l p t}^{\prime} \lambda+X_{l t}^{\prime} \beta\right)}{\sum_{k=1}^{m} \exp \left(A_{k w t}^{\prime} \gamma+A_{k p t}^{\prime} \lambda+X_{k t}^{\prime} \beta\right)}
$$

Results for the likelihood of entry are reported in Table 8. In all model specifications, the localization of remediation activity is important, all else equal. The estimated coefficient of the variable that uses the number of existing remediation firms as a measure of industrial concentration is positive and significant at the .01 level. In other words, the presence of incumbent remediation firms has a positive impact on the likelihood of additional entry of remediation firms. This is consistent with the presence of localization economies, or economies of scale from industrial concentration, that enhance the attractiveness of a given location for a start-up or relocating establishment. Not surprisingly, the presence of TRI-type firms matters with consistently and highly significant coefficient estimates across all models.

This indicates that industries with a history of polluting firms are an important factor in the presence of remediation firms. The estimated coefficient on median income is also significant and positive and there is some evidence that the second derivative on the median income variable may be negative or the relationship is concave. We also conclude that population matters, as does land area. The signs of the coefficients for both variables, ceteris paribus, imply that greater population density, as would be expected, results in a higher likelihood of entry of remediation establishments. Of further 
interest is the estimated coefficient on the ratio of college-educated residents. These results suggest that higher levels of education correlate to lower remediation firm entry probabilities.

As a robustness check, we estimate the entry process using a count data model with time fixed effects, specifically a Poisson model estimated by Pseudo Maximum Likelihood (PPML). Our dependent variable is the number of waste management entrants $(y)$ for a given tract $(l)$ for a given year $(t)$. The basic model is as follows:

$$
E\left[y_{l t} \mid A_{l w t}, A_{l p t}, X_{l t}\right]=\exp \left(A_{l w t}^{\prime} \nu+A_{l p t}^{\prime} \omega+X_{l t}^{\prime} \psi+\tau_{l t}\right)
$$

Estimation results for these PPML regressions are contained in Table 9. No qualitative differences are observed between these two models. As before, there is evidence of localization effects and demandside factors associated with a larger TRI-type firm sector on the likelihood of remediation firm entry. In summary, the above findings support our earlier conjecture that remediation firms will locate closer to TRI-type firms.

\subsection{Entry at random locations}

As an additional robustness check, we look at entry by establishments in the remediation industries into random locations that are not dependent on legal jurisdictional boundaries. The locations are defined as non-overlapping rings of one-mile radius centered on establishments that are not in the defined set of remediation industries -that is, establishments in either a TRI-type or a non-TRI-type industry, excluding the remediation sector.

This brings an additional level of spatial acuity into the analysis. We center the rings on existing establishments because we want to limit the analysis to areas where there is commercial activity in order to ensure that the chosen areas are actually potential choices for locating a new establishment. Not doing so might result in choosing locations in which there is virtually no population, such as remote rural or agricultural land with no industrial or commercial infrastructure, or no commercial or industrial activity due to, say, zoning restrictions. Any non-remediation industry establishment that existed at any point during the time frame of the study is a potential center point, thus allowing for the possibility of new areas of commercial activity that came into existence during the course of the analysis and the possibility that a remediation firm is the first to enter the area. 
By maximizing the number of potential rings while imposing the non-overlapping condition, we get 8,142 rings. Table 10 provides summary statistics for these non-overlapping rings. We see 231 out of 395 entrants enter into these random locations. Figure 3 shows these locations.

The specific industry containing the firm that is used to center the random location ring does not matter -it only serves to locate a ring in an area that allows commercial activity. It is, rather, the industrial content captured in the ring that matters. In this analysis, the variables of interest are remediation industry establishments and TRI-type firms contained in the random rings. We are unable to measure non-establishment variables, such as household income or other population characteristics, at the spatial division of the rings. Hence, the other variables in the model are still measured at the census tract level and reflect the census tract in which the ring center is located. In general, this represents measures for the census tract variable values that reflect the tract in which the majority of the area of the ring is located.

The results of the PPML estimation in Table 11 are quite similar to those based on establishments at the census tract. That is, localization is, as before, an important determinant of the likelihood of remediation establishment entry. Further, the presence of TRI-type establishments in the rings is an important factor in location decisions of remediation industry establishments. Of interest, higher wages in the surrounding census tract are significantly associated with higher entry probabilities which can reflect the industry's demand for higher skilled labor.

\subsection{Exit}

Thinking about establishment exits, we have in mind a theoretical model involving a threshold rule that is analogous to the profit maximization problem considered in our entry analysis. In this case, if firms do not make a sufficient level of profit, they choose to exit the industry. In order to consider the question of remediation industry establishment exit, we estimate logit models in which the dependent variable is coded one if the firm exits during a given period, or as zero if the firm continues operation through the entire period.

Exit is identified as having taken place if the firm (EIN) disappears from the data set at the outset of a given calendar year and is treated as having occurred during the last year in which the firm is 
present in the data (year previous to disappearance). The time to failure is relative to the year in which the firm entered the market. That is, we only consider firms that enter during the time frame of the analysis, i.e., entry in years 2000-2006, and consider the exit event relative to the number of years since entry. The observed number of years to failure, therefore, ranges from a low of one (failure in year of entry) to a high of seven (no failure observed) across the establishments in the sample. Table 12 illustrates exit patterns. To interpret Table 12, note that, in year 2002, there were 98 entrants. By 2006, or over the course of the following five years, 69 of them exited the market.

Overall, there were 395 entrants of which 214 of them had exited by 2006 . Table 13 provides establishment-level summary statistics. About $36 \%$ of the establishments have past experience in the market. On average, these establishments have an additional branch or are part of a multiestablishment firm. Additionally, these establishments pay about $\$ 49,000$ per year in wages and employ about 19 workers. This indicates that this labor force is highly skilled and limited to a given area. Hence, we conjecture that firms will compete for the same resources and this will affect the survival rate. In this case, we expect agglomeration to increase the likelihood of exit.

Estimation results are reported in Table 14. In the case of localization effects, the presence of other remediation firms increases the likelihood of failure for these new establishments. On the other hand, the numbers of local area TRI-type firms appear to have no influence on exit probabilities. Not surprisingly, like firms in most industries, the age of the firm and firm size (employment) are negatively correlated with probability of failure in any given period. As with the other estimations above, local income appears to have no statistically significant effect on exit.

\section{Conclusion}

We have employed detailed data for small geographies to analyze the posited theoretical relationship between the localization of potentially polluting firms, toxic releases, and local-area incomes. Our model suggests that profit-maximizing, potentially polluting firms behave rationally toward the finan-

cial risk inherent in a toxic release. Our conjecture is that, as risk exposure increases with incomes within spatial proximity to those firms, the firms will take measures to manage that risk. We utilized the localization of the waste management industry as a means of observing evidence of demand for 
risk-reducing options. In this context, firms can vary their utilization of waste management services as an additional means of managing pollution risk across the spectrum of locations in lower income, lower risk exposure areas to location in higher income, higher risk exposure areas.

We find our results to be persuasive. We find evidence consistent with our hyotheses, both in terms of potentially polluting firms' localization, the localization of waste remediation firms, and in terms of the relative frequency of these firms' reported releases. (Hypotheses 1, 2 and 3.) Since the analysis was made within a single state, we have largely controlled for heterogeneity in regulatory structures that, under the traditional pollution haven argument, would lead to a similar result in terms of realized releases if polluting firms were to exploit opportunities to locate in lower income areas anxious to attract employers by providing relatively lax regulatory environments. While both explanations will lead to a similar outcome, ours is driven by non-policy related incentives, although it does depend on enforcement of a common set of laws. That is to say, the traditional economic paradigm of profitmaximizing behavior in the presence of risk can explain the phenomenon of the local EKC independent of any differences across regulatory regimes.

Our results bear implications for policies that aim to enhance environmental justice, but also speaks to policies that can exploit the incentives inherent in the standard paradigm of profit-maximization. One of the objectives of the TRI Program was to create a strong incentive for companies to take measures to reduce their toxic release and be good neighbors in their communities. During our sample period 2000-2006, overall toxic releases in the US decreased by about $34 \%$ with a further decline of about $21 \%$ since 2006 . However, our paper shows that this decline might not be uniformly distributed because firms respond to local demographic characteristics (including local income). In trying to implement the lowest-cost response to the publication of the TRI data, firms will tend to reduce releases through waste management when local opposition is the highest.

Combined with our finding that economic activity and local income are positively correlated, this implies that the population group most affected by toxic releases will be a working-class population located in an industrial area. Our analysis suggests that without further actions, the disparities in exposure to toxic release faced by certain population groups will not be reduced by simply requiring that firms report their releases. If the attainment of greater environmental justice across population 
groups is a policy goal, serious thought should then be given to the regulations on compensation schemes, designed to offset the costs of potential environmental risk. 


\section{References}

[1] Arora, S., and Cason, T. N. (1999). Do community characteristics influence environmental outcomes? Evidence from the Toxic Release Inventory, Southern Economic Journal, 65(4), 691-716.

[2] Brooks, N., and Sethi, R.(1997). The distribution of pollution: community characteristics and exposure to air toxics, Journal of Environmental Economics and Management, 32, 233-250.

[3] Coase, R. H. (1960), The Problem of Social Cost, The Journal of Law \& Economics, 3, 1-44.

[4] Combes, P. (2000). Economic structure and local growth: France 1984-1993, Journal of Urban Economics, 47 , 329-355.

[5] Currie, J., Davis, L., Greenstone, M., and Walker, R. (2015). Environmental health risks and housing values: evidence from 1,600 toxic plant openings and closings. American Economic Review, 105(2), 678-709.

[6] de Bruyn, S. M., and Heintz, R. J. (1999). The Environmental Kuznets Curve Hypothesis. Chapters,in: Handbook of Environmental and Resource Economics, chapter 46. Edward Elgar Publishing.

[7] De Marchi, S., and Hamilton, J. T. (2006). Assessing the accuracy of self-reported data: an evaluation of the toxics release inventory. Journal of Risk and uncertainty, 32(1), 57-76.

[8] De Silva, D. G., Hubbard T., and Schiller, A. R. (2016). Entry and Exit Patterns of 'Toxic' Firms, The American Journal of Agricultural Economics, 98 (3), 881-909.

[9] Fischel, W.A. (2005). The Home voter Hypothesis: How Home Values Influence Local Government Taxation, School Finance, and Land-Use Policies. Harvard University Press.

[10] Florida, R. and Davison, D. (2001). Why do firms adopt (advanced) environmental management practices (And do they make a difference?). In Regulating from the Inside, ed. C. Coglianese and J. Nash, RFF Press: Washington D.C. 
[11] Gamper-Rabindran, S. (2006). Did the EPA's voluntary industrial toxics program reduce emissions? A GIS analysis of distributional impacts and by-media analysis of substitution. Journal of environmental economics and management, 52(1), 391-410.

[12] Glaeser, E. L., Kallal, H. L., Scheinkman, J. A., Schliefer, A. (1992). Growth in cities, Journal of Political Economy, 100 , 1126-1152.

[13] Gourieroux, C., Monfort, A. and Trognon, A. (1984). Pseudo Maximum Likelihood Methods: Applications to Poisson Models, Econometrica, 52, 701-720.

[14] Grossman, G. M., and Krueger, A. B. (1993). Environmental impacts of a North American freetrade agreement, in The U.S.-Mexico Free Trade Agreement, P. Garber, (ed.), MIT Press, Cambridge, MA.

[15] Grossman, G. M., and Krueger, A. B. (1995). Economic growth and the environment, Quarterly Journal of Economics, 110, 353-378.

[16] Hamilton, J. H. (1995). Testing for environmental racism: Prejudice, profits, political power? Journal of Policy Analysis and Management, 14, 107-132.

[17] Harbaugh, W. T., Levinson, A., and Wilson, D. M. (2002). Reexamining the Empirical Evidence for an Environmental Kuznets Curve, Review of Economics and Statistics, 84 (3), 541-551.

[18] Harrington, D.R. (2012). Two-stage Adoption of Different Types of Pollution Prevention Technologies, Resource and Energy Economics, 34(3), 349-373.

[19] Harrington, D.R. (2013). Effectiveness of State Pollution Prevention (P2) Programs and Policies, Contemporary Economic Policy, 31(2), 255-278.

[20] Henderson, V., Kuncoro, A., and Turner, M. (1995). Industrial development in cities, Journal of Political Economy, 103, 1067-1090.

[21] Keller, W., and A. Levinson. (2002). Pollution Abatement Costs and Foreign Direct Investment Inflows to U.S. States. Review of Economics and Statistics 84, 691-703. 
[22] Khanna, M., Deltas, G., and Harrington, D.R. (2009). Adoption of Pollution Prevention Techniques: The Role of Management Systems, Demand-Side Factors and Complementary Assets. Environmental and Resource Economics, 44(1), 85-106.

[23] Koehler, D. A., and Spengler, J. D. (2007). The toxic release inventory: Fact or fiction? A case study of the primary aluminum industry. \msipassthru \{Journal of Environmental Management\}, 85(2), 296-307.

[24] Levinson, A. (1996). Environmental regulations and manufacturers' location choices: Evidence from the Census of Manufactures, Journal of Public Economics, 62 (1-2), 5-29.

[25] List, J.A., and C.Y. Co. (2000). The Effects of Environmental Regulations on Foreign Direct Investment. Journal of Environmental Economics and Management, 40(1), 1-20.

[26] List, J.A., W.W. McHone, and D.L. Millimet. (2003). Effects of Air Quality Regulation on the Destination Choice of Relocating Plants. Oxford Economic Papers 55, 657-678.

[27] McFadden, D. L., (1974). Conditional logit analysis of qualitative choice behavior, Frontiers in Economics, P. Zarembka (ed.), Academic Press: New York, 105-142.

[28] Olson, M. (1965). The logic of collective action. Cambridge, MA: Harvard.

[29] Papke, L. E., and Wooldridge, J. M. (1996). Econometric Methods for fractional response variables with an application to 401(K) plan participation rates, Journal of Applied Econometrics, 11, 619632.

[30] Rosenthal, S. S., and Strange, W. C. (2003). Geography, industrial organization, and agglomeration, Review of Economics and Statistics, 85, 377-393.

[31] Sam, A. G. (2010). Impact of government-sponsored pollution prevention practices on environmental compliance and enforcement: evidence from a sample of US manufacturing facilities. Journal of Regulatory Economics, 37(3), 266-286.

[32] Santos Silva, J.M., and Tenreyro, S. (2006). The Log of Gravity, Review of Economics and Statistics, 88 (4), 641-58. 
[33] — , (2011). Further Simulation Evidence on the Performance of the Poisson Pseudo-Maximum Likelihood Estimator, Economics Letters 112 (2), 220-2.

[34] Shadbegian, R., and Wolverton, A. (2012). Location Decisions of U.S. Polluting Plants: Theory, Empirical Evidence, and Consequences, International Review of Environmental and Resource Economics, 4(1), 1-49.

[35] Stern, D. I. (2004). The rise and fall of the environmental Kuznets curve, World Development, 32(8), 1419-1439.

[36] Wolverton, A. (2009). Effects of Socio-Economic and Input-Related Factors on Polluting Plants' Location Decisions. The B.E. Journal of Economic Analysis 83 Policy, 9, 1-32. 


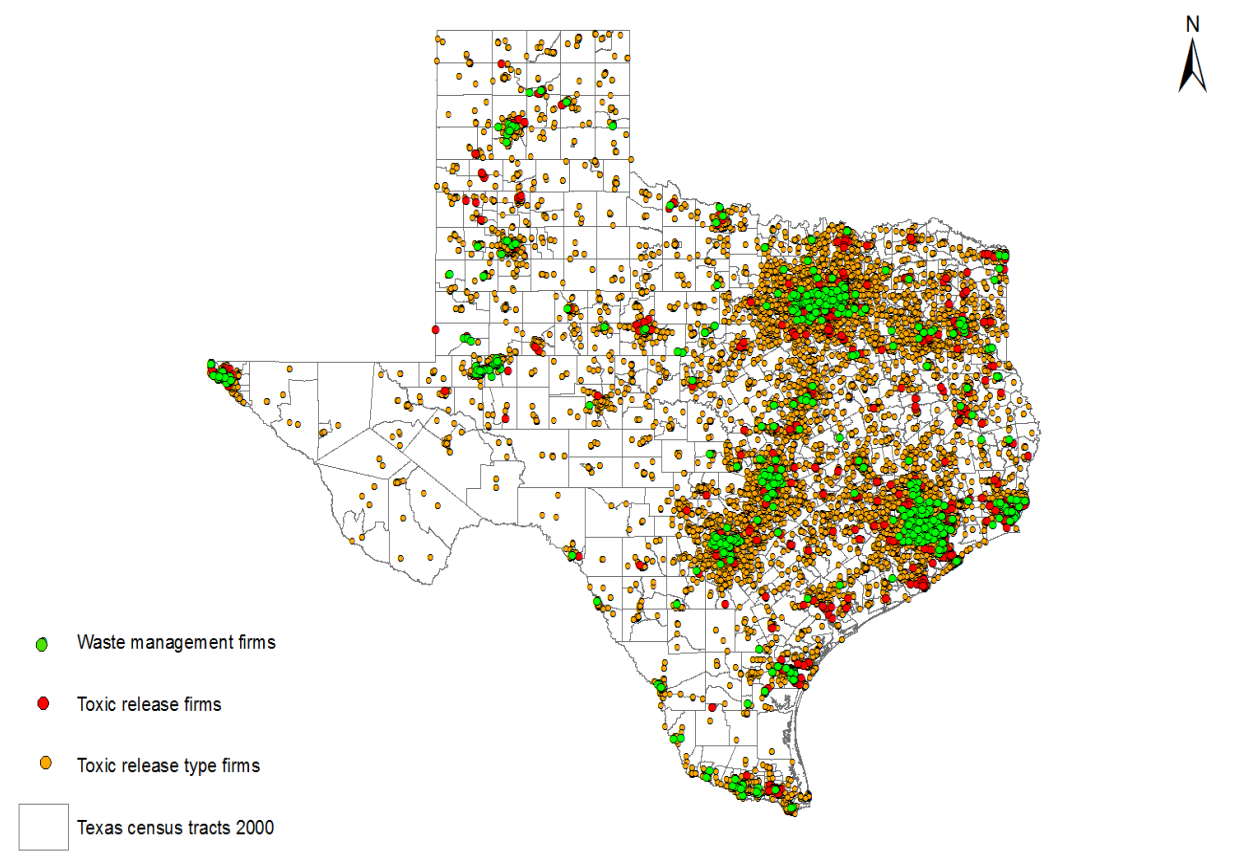

Figure 1: Locations of waste remediation and TRI firms

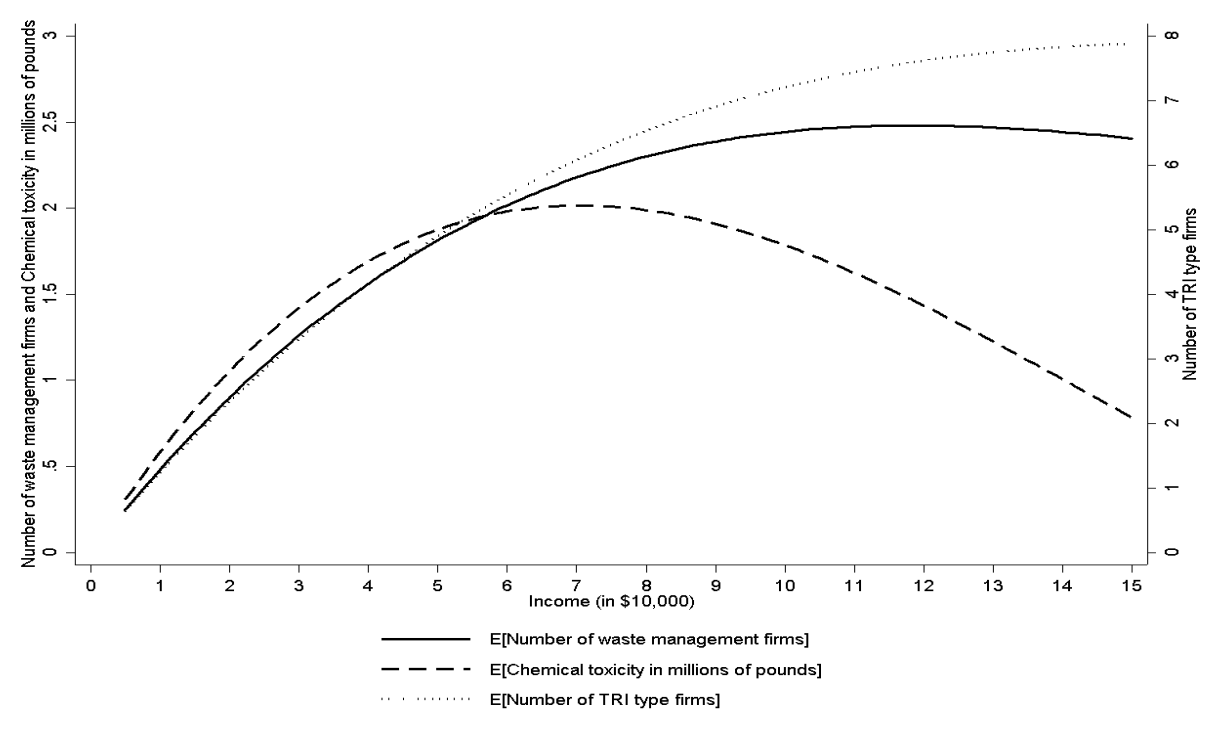

Figure 2: Estimated cubic functions relating number of firms to median income 


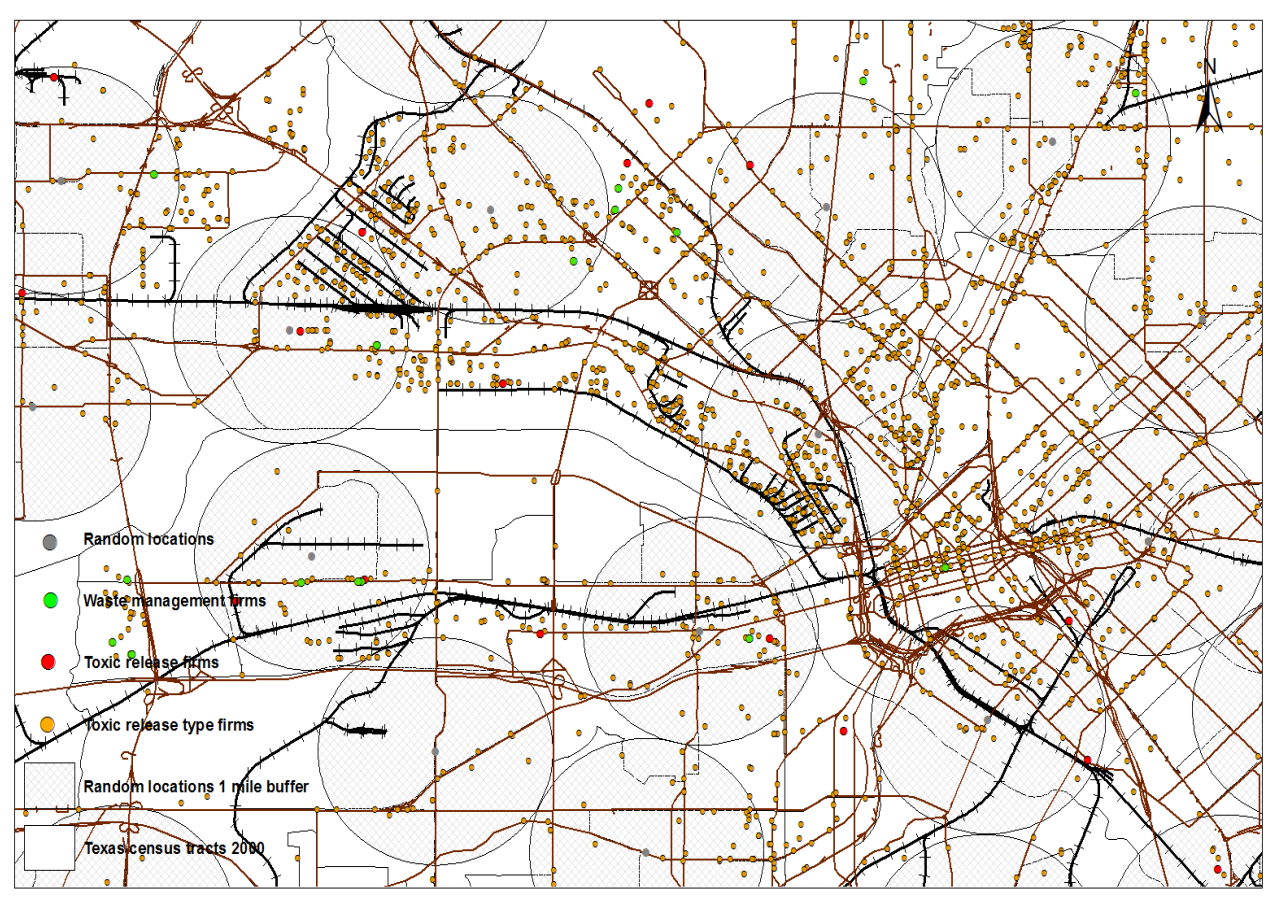

Figure 3: Non-overlapping one mile rings - Dallas area 
Table 1: Summary statistics by tract

\begin{tabular}{|c|c|}
\hline Variable & Mean (Standard deviation) \\
\hline Average toxicity in pounds ${ }_{l t}$ (in millions) & $\begin{array}{c}0.010 \\
(0.180)\end{array}$ \\
\hline Average number of environmental remediation firms ${ }_{l t}$ & $\begin{array}{c}0.084 \\
(0.342)\end{array}$ \\
\hline Average number of TRI type firms ${ }_{l t}$ & $\begin{array}{l}4.018 \\
(9.994)\end{array}$ \\
\hline Average number of employees in TRI-type firms per tract ${ }_{l t}$ & $\begin{array}{c}15.576 \\
(73.939)\end{array}$ \\
\hline Median income (in $\$ 10,000)_{l t}$ & $\begin{array}{c}4.393 \\
(2.278)\end{array}$ \\
\hline Average wage (in $\$ 10,000)_{l t}$ & $\begin{array}{c}3.825 \\
(4.470)\end{array}$ \\
\hline College ratio $_{l t}$ & $\begin{array}{c}0.094 \\
(0.078)\end{array}$ \\
\hline Number of amenity establishments $_{l t}$ & $\begin{array}{c}5.478 \\
(12.878)\end{array}$ \\
\hline Number of roads $_{l t}$ & $\begin{array}{c}13.150 \\
(12.022)\end{array}$ \\
\hline Number of rail roads ${ }_{l t}$ & $\begin{array}{c}2.153 \\
(4.154)\end{array}$ \\
\hline 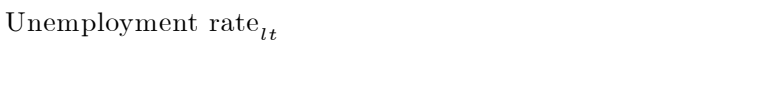 & $\begin{array}{l}4.468 \\
(3.204)\end{array}$ \\
\hline Population (in 1,000$)_{l t}$ & $\begin{array}{l}5.088 \\
(2.884)\end{array}$ \\
\hline Land area (in 100 in square miles) $)_{l t}$ & $\begin{array}{c}0.622 \\
(2.200)\end{array}$ \\
\hline Housing rental ratio $_{l t}$ & $\begin{array}{c}0.315 \\
(0.201)\end{array}$ \\
\hline TxDOT expenditures (in $\$ 1,000,000)_{l t}$ & $\begin{array}{c}9.068 \\
(23.076)\end{array}$ \\
\hline Average house value (in $\$ 10,000)_{l t}$ & $\begin{array}{l}11.423 \\
(9.619)\end{array}$ \\
\hline
\end{tabular}




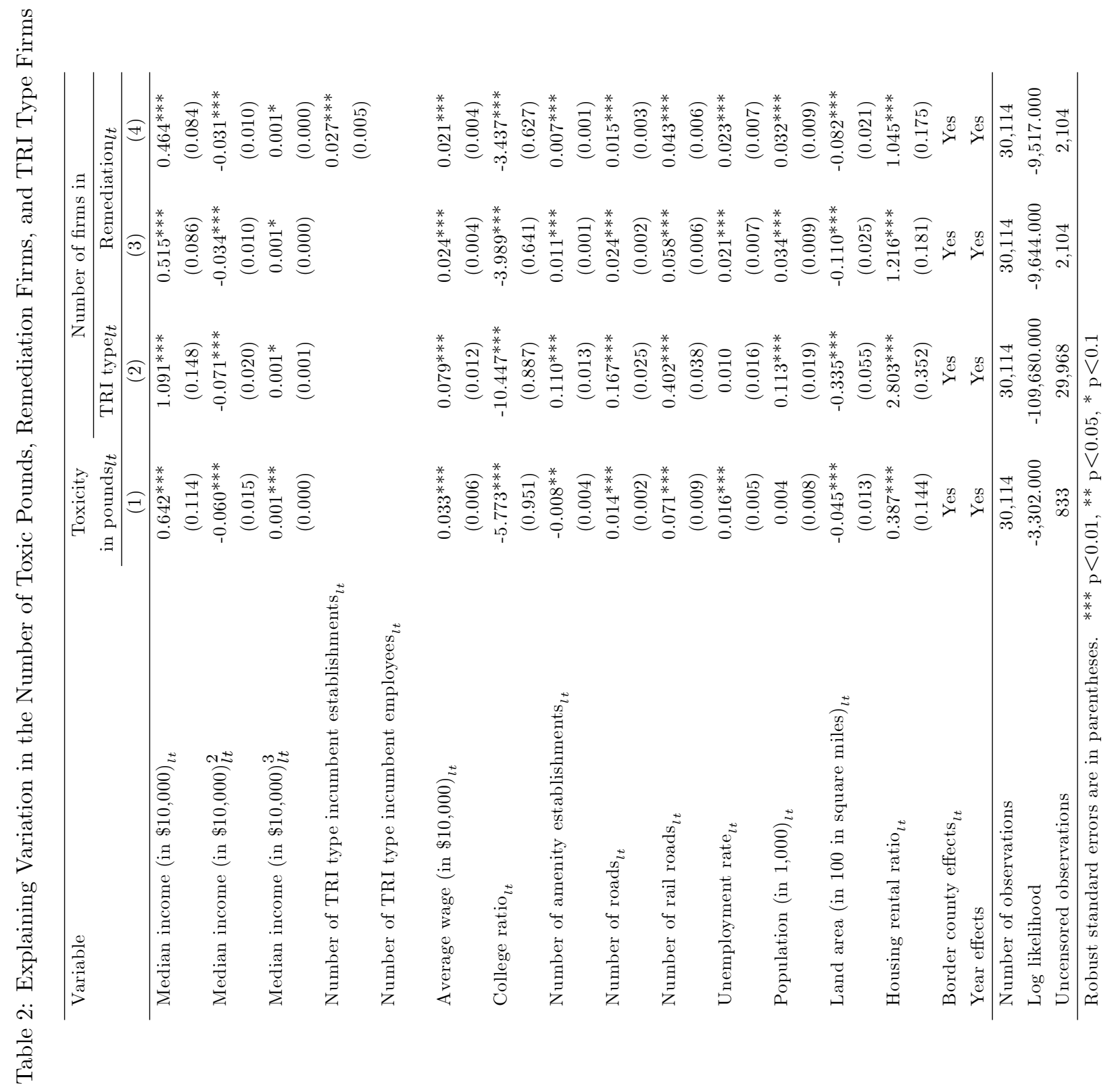




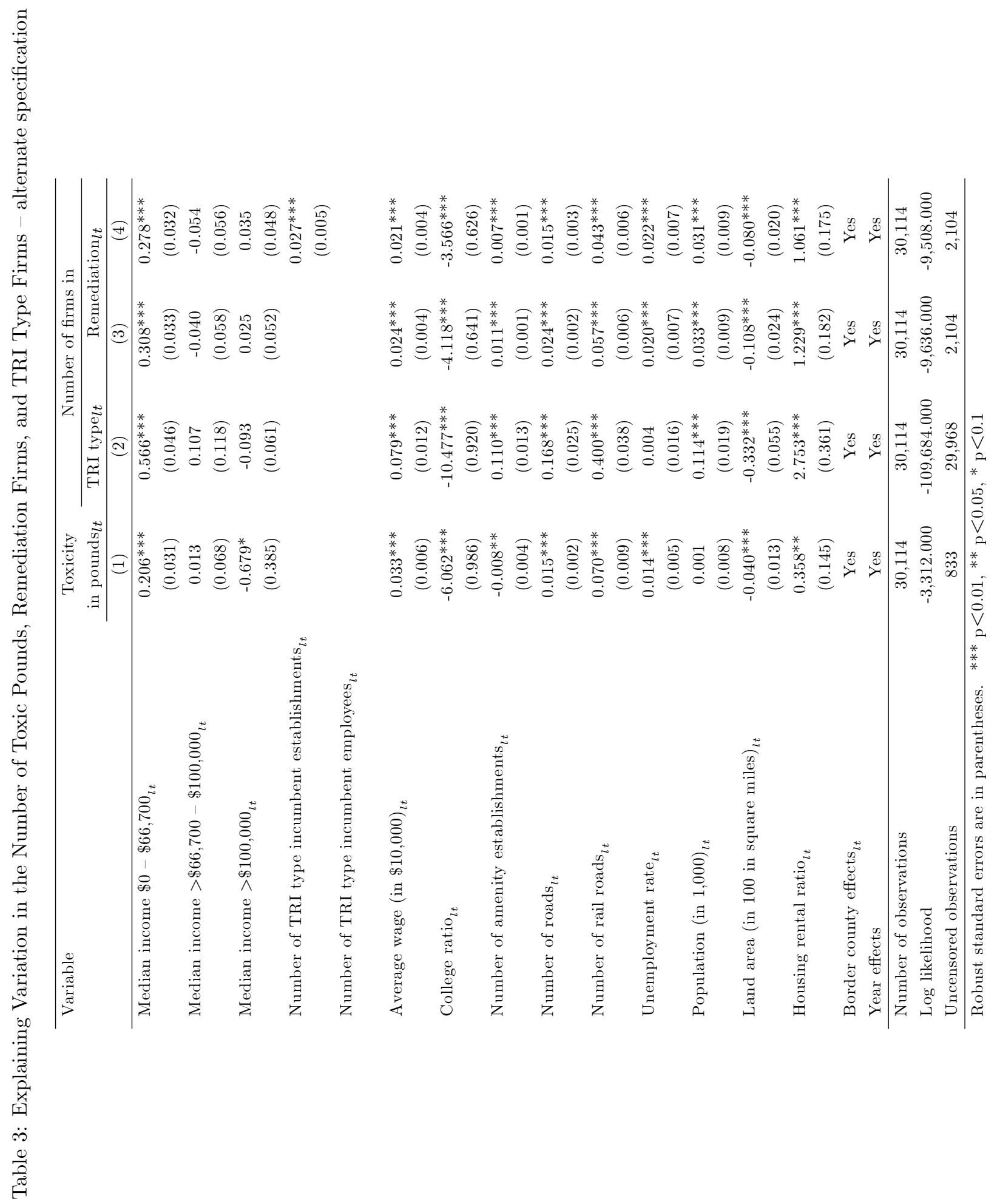


Table 4: Relative frequency of toxic release firms reported

\begin{tabular}{|c|c|c|c|}
\hline \multirow[t]{2}{*}{ Variable } & \multicolumn{3}{|c|}{ (TRI polluters / TRI-type firms) $l t$} \\
\hline & $(1)$ & $(2)$ & $(3)$ \\
\hline Median income $\$ 0-\$ 66,700_{l t}$ & $\begin{array}{c}-0.036^{* * *} \\
(0.011)\end{array}$ & $\begin{array}{c}-0.033^{* * *} \\
(0.012)\end{array}$ & $\begin{array}{c}-0.031^{* *} \\
(0.014)\end{array}$ \\
\hline Median income $>\$ 66,700-\$ 100,000_{l t}$ & $\begin{array}{l}-0.038 \\
(0.040)\end{array}$ & $\begin{array}{l}-0.034 \\
(0.040)\end{array}$ & $\begin{array}{l}-0.044 \\
(0.042)\end{array}$ \\
\hline Median income $>\$ 100,000_{l t}$ & $\begin{array}{c}-0.259^{*} \\
(0.138)\end{array}$ & $\begin{array}{c}-0.260^{*} \\
(0.135)\end{array}$ & $\begin{array}{c}-0.289^{*} \\
(0.154)\end{array}$ \\
\hline Average wage (in $\$ 10,000)_{l t}$ & & & $\begin{array}{c}0.014^{* * *} \\
(0.002)\end{array}$ \\
\hline Number of amenity establishments ${ }_{l t}$ & & & $\begin{array}{c}-0.020 * * * \\
(0.003)\end{array}$ \\
\hline Number of roads $s_{l t}$ & & & $\begin{array}{c}0.003^{* *} \\
(0.001)\end{array}$ \\
\hline Number of rail roads $_{l t}$ & & & $\begin{array}{c}0.026^{* * *} \\
(0.002)\end{array}$ \\
\hline 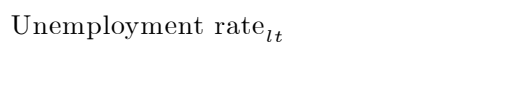 & & & $\begin{array}{c}0.003 \\
(0.005)\end{array}$ \\
\hline Population (in 1,000$)_{l t}$ & & $\begin{array}{c}-0.013^{*} \\
(0.007)\end{array}$ & $\begin{array}{l}-0.002 \\
(0.006)\end{array}$ \\
\hline Land area (in 100 in square miles) ${ }_{l t}$ & & $\begin{array}{c}0.003 \\
(0.005)\end{array}$ & $\begin{array}{c}-0.016^{*} \\
(0.009)\end{array}$ \\
\hline Housing rental ratio $_{l t}$ & & & $\begin{array}{l}-0.029 \\
(0.110)\end{array}$ \\
\hline Year effects & Yes & Yes & Yes \\
\hline Border county effects $_{l t}$ & Yes & Yes & Yes \\
\hline Number of observations & 30,114 & 30,114 & 30,114 \\
\hline Log likelihood & $-1,215.000$ & $-1,214.000$ & $-1,178.000$ \\
\hline
\end{tabular}


Table 5: Relative frequency of toxic release firms reported by industry

\begin{tabular}{|c|c|c|c|}
\hline \multirow[t]{2}{*}{ Variable } & $\begin{array}{l}\text { (Chemical polluters / } \\
\text { total chemical firms) } l t\end{array}$ & $\begin{array}{c}\text { (Fabricated metal polluters / } \\
\text { total fabricated metal) } l t\end{array}$ & $\begin{array}{c}\text { (Miscellaneous manuf. polluters / } \\
\text { total miscellaneous manuf.) } l t\end{array}$ \\
\hline & $(1)$ & $(2)$ & $(3)$ \\
\hline \multirow[t]{2}{*}{ Median income $\$ 0-\$ 66,700_{l t}$} & -0.005 & 0.013 & 0.012 \\
\hline & $(0.012)$ & $(0.013)$ & $(0.029)$ \\
\hline \multirow{2}{*}{ Median income $>\$ 66,700-\$ 100,000_{l t}$} & -0.026 & $-0.213^{* * *}$ & -0.034 \\
\hline & $(0.038)$ & $(0.046)$ & $(0.053)$ \\
\hline \multirow[t]{2}{*}{ Average wage (in $\$ 10,000)_{l t}$} & $0.018^{* * *}$ & $0.008^{* * *}$ & $0.008^{* * *}$ \\
\hline & $(0.002)$ & $(0.002)$ & $(0.002)$ \\
\hline \multirow{2}{*}{ Number of amenity establishments $_{l t}$} & 0.001 & $0.001 * * *$ & $0.002^{* * *}$ \\
\hline & $(0.001)$ & $(0.000)$ & $(0.001)$ \\
\hline Number of roads $s_{l t}$ & $0.006^{* * *}$ & $0.009^{* * *}$ & $0.010^{* * *}$ \\
\hline \multirow[t]{2}{*}{ 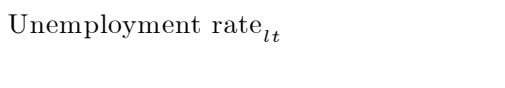 } & $0.023^{* * *}$ & $0.013^{* * *}$ & -0.011 \\
\hline & $(0.003)$ & $(0.004)$ & $(0.020)$ \\
\hline \multirow{2}{*}{ Population (in 1,000$)_{l t}$} & $0.020^{* * *}$ & $0.035^{* * *}$ & $0.040^{* * *}$ \\
\hline & $(0.005)$ & $(0.005)$ & $(0.007)$ \\
\hline \multirow[t]{2}{*}{ Land area (in 100 in square miles) ${ }_{l t}$} & $-0.019^{*}$ & $-0.068^{* * *}$ & -0.038 \\
\hline & $(0.010)$ & $(0.021)$ & $(0.024)$ \\
\hline \multirow[t]{2}{*}{ Housing rental ratio $_{l t}$} & 0.058 & $-0.361^{* * *}$ & $0.591^{* * *}$ \\
\hline & $(0.087)$ & $(0.097)$ & $(0.143)$ \\
\hline Year effects & Yes & Yes & Yes \\
\hline Border county effects $_{l t}$ & Yes & Yes & Yes \\
\hline Number of observations & 30,114 & 30,114 & 30,114 \\
\hline
\end{tabular}




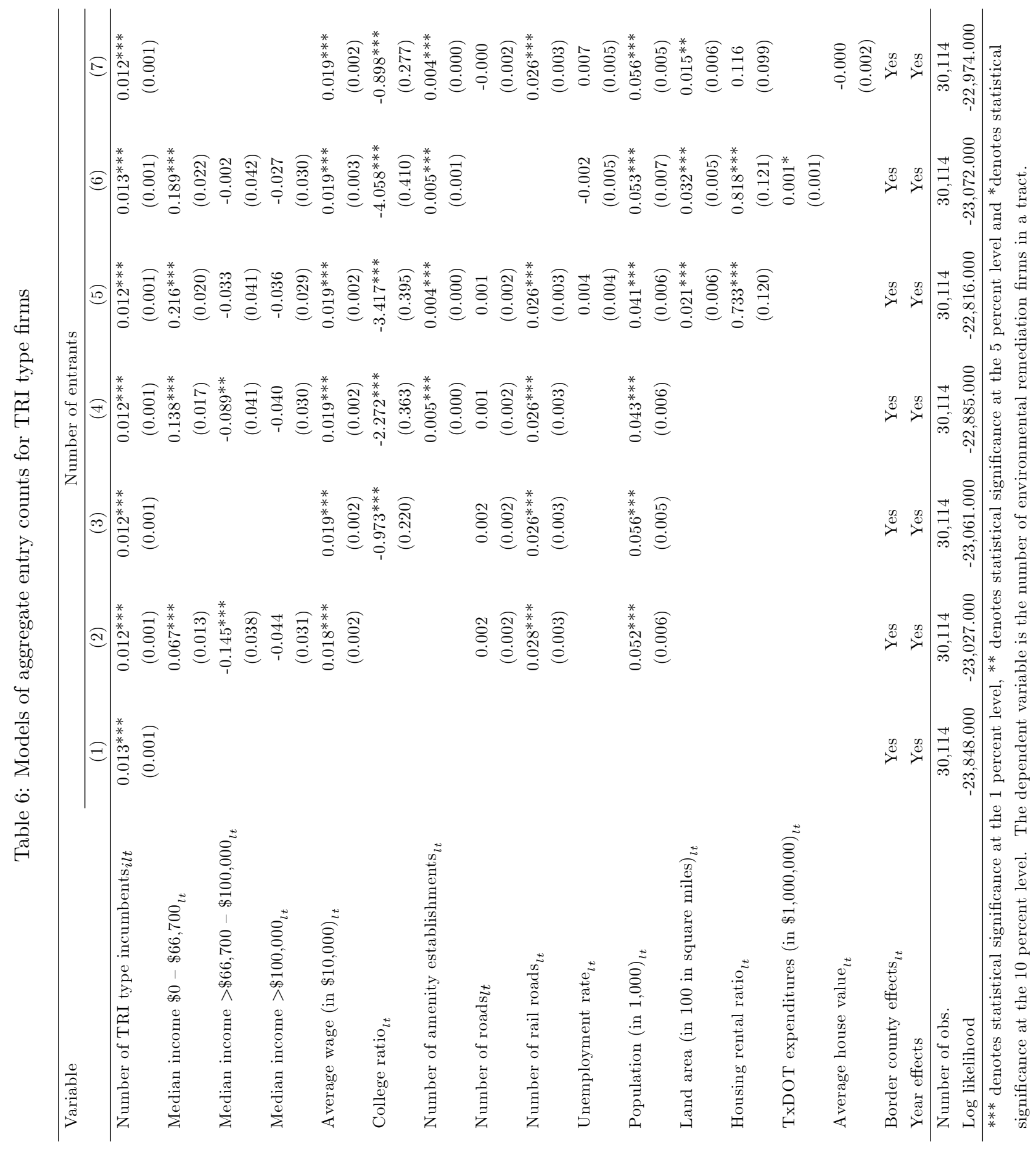


Table 7: Entry patterns

\begin{tabular}{lcc}
\hline \multirow{2}{*}{ Entry year } & \multicolumn{2}{c}{ Remediation firm } \\
\cline { 2 - 3 } & Entrants & Incumbents \\
\hline 2000 & 43 & 203 \\
2001 & 47 & 241 \\
2002 & 98 & 277 \\
2003 & 54 & 362 \\
2004 & 58 & 367 \\
2005 & 50 & 368 \\
2006 & 45 & 375 \\
\hline
\end{tabular}


Table 8: Conditional logit results for firm entry at tract level

\begin{tabular}{|c|c|c|c|c|c|c|c|}
\hline \multirow[t]{2}{*}{ Variable } & \multicolumn{7}{|c|}{ Firm entry } \\
\hline & $(1)$ & $(2)$ & $(3)$ & $(4)$ & $(5)$ & $(6)$ & $(7)$ \\
\hline $\begin{array}{l}\text { Number of environmental remediation } \\
\text { incumbents }_{l t}\end{array}$ & $\begin{array}{c}1.048^{* * *} \\
(0.059)\end{array}$ & $\begin{array}{c}1.008^{* * *} \\
(0.063)\end{array}$ & $\begin{array}{c}1.027^{* * *} \\
(0.063)\end{array}$ & $\begin{array}{c}0.980^{* * *} \\
(0.064)\end{array}$ & $\begin{array}{c}0.960^{* * *} \\
(0.066)\end{array}$ & $\begin{array}{c}0.990 * * * \\
(0.062)\end{array}$ & $\begin{array}{c}1.019^{* * *} \\
(0.064)\end{array}$ \\
\hline Number of TRI type incumbentsilt & $\begin{array}{c}0.008^{* * *} \\
(0.001)\end{array}$ & $\begin{array}{c}0.006^{* * *} \\
(0.002)\end{array}$ & $\begin{array}{c}0.005^{* * *} \\
(0.002)\end{array}$ & $\begin{array}{c}0.005^{* * *} \\
(0.002)\end{array}$ & $\begin{array}{c}0.004^{* *} \\
(0.002)\end{array}$ & $\begin{array}{c}0.008^{* * * *} \\
(0.001)\end{array}$ & $\begin{array}{l}0.004^{* *} \\
(0.002)\end{array}$ \\
\hline Median income $\$ 0-\$ 66,700_{l t}$ & & $\begin{array}{c}0.160^{* * *} \\
(0.042)\end{array}$ & & $\begin{array}{c}0.265^{* * *} \\
(0.052)\end{array}$ & $\begin{array}{c}0.391^{* * *} \\
(0.061)\end{array}$ & $\begin{array}{c}0.376^{* * *} \\
(0.062)\end{array}$ & \\
\hline Median income $>\$ 66,700-\$ 100,000_{l t}$ & & $\begin{array}{l}-0.084 \\
(0.091)\end{array}$ & & $\begin{array}{c}0.001 \\
(0.095)\end{array}$ & $\begin{array}{c}0.088 \\
(0.098)\end{array}$ & $\begin{array}{c}0.077 \\
(0.098)\end{array}$ & \\
\hline Median income $>\$ 100,000_{l t}$ & & $\begin{array}{c}0.001 \\
(0.089)\end{array}$ & & $\begin{array}{c}0.005 \\
(0.088)\end{array}$ & $\begin{array}{l}-0.001 \\
(0.086)\end{array}$ & $\begin{array}{c}0.015 \\
(0.087)\end{array}$ & \\
\hline Average wage (in $\$ 10,000)_{l t}$ & & $\begin{array}{l}0.013^{*} \\
(0.007)\end{array}$ & $\begin{array}{c}0.016^{* *} \\
(0.007)\end{array}$ & $\begin{array}{c}0.015^{* *} \\
(0.007)\end{array}$ & $\begin{array}{l}0.013^{*} \\
(0.007)\end{array}$ & $\begin{array}{c}0.014^{* *} \\
(0.007)\end{array}$ & $\begin{array}{c}0.014^{* *} \\
(0.007)\end{array}$ \\
\hline College ratio $_{l t}$ & & & $\begin{array}{c}0.080 \\
(0.706)\end{array}$ & $\begin{array}{c}-3.326^{* * *} \\
(1.082)\end{array}$ & $\begin{array}{c}-5.050^{* * *} \\
(1.215)\end{array}$ & $\begin{array}{c}-5.307^{* * *} \\
(1.221)\end{array}$ & $\begin{array}{l}-0.444 \\
(0.880)\end{array}$ \\
\hline Number of amenity establishments $_{l t}$ & & & & $\begin{array}{c}0.004^{* * *} \\
(0.001)\end{array}$ & $\begin{array}{c}0.003^{* * *} \\
(0.001)\end{array}$ & $\begin{array}{c}0.003^{* * *} \\
(0.001)\end{array}$ & $\begin{array}{c}0.003^{* * *} \\
(0.001)\end{array}$ \\
\hline Number of roads $s_{l t}$ & & $\begin{array}{c}0.004 \\
(0.004)\end{array}$ & $\begin{array}{c}0.002 \\
(0.004)\end{array}$ & $\begin{array}{c}0.003 \\
(0.004)\end{array}$ & $\begin{array}{c}0.006 \\
(0.004)\end{array}$ & & $\begin{array}{c}0.004 \\
(0.004)\end{array}$ \\
\hline Number of rail roads $_{l t}$ & & $\begin{array}{c}0.019 * * \\
(0.009)\end{array}$ & $\begin{array}{c}0.018^{* *} \\
(0.009)\end{array}$ & $\begin{array}{l}0.017^{*} \\
(0.009)\end{array}$ & $\begin{array}{c}0.019 * * \\
(0.009)\end{array}$ & & $\begin{array}{c}0.020^{* *} \\
(0.009)\end{array}$ \\
\hline 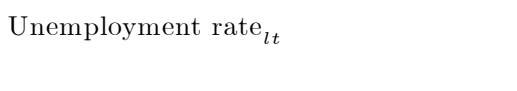 & & & & & $\begin{array}{c}0.013 \\
(0.011)\end{array}$ & $\begin{array}{c}0.013 \\
(0.011)\end{array}$ & $\begin{array}{c}0.021^{*} \\
(0.013)\end{array}$ \\
\hline Population (in 1,000$)_{l t}$ & & $\begin{array}{c}0.052^{* * *} * \\
(0.015)\end{array}$ & $\begin{array}{c}0.068^{* * *} \\
(0.014)\end{array}$ & $\begin{array}{c}0.041^{* * *} \\
(0.016)\end{array}$ & $\begin{array}{c}0.038^{* *} \\
(0.016)\end{array}$ & $\begin{array}{c}0.044^{* * *} \\
(0.015)\end{array}$ & $\begin{array}{c}0.067^{* * *} \\
(0.014)\end{array}$ \\
\hline Land area (in 100 in square miles) $)_{l t}$ & & & & & $\begin{array}{l}-0.052 \\
(0.037)\end{array}$ & $\begin{array}{l}-0.023 \\
(0.032)\end{array}$ & $\begin{array}{l}-0.076^{*} \\
(0.042)\end{array}$ \\
\hline Housing rental ratio ${ }_{l t}$ & & & & & $\begin{array}{c}1.211^{* * *} \\
(0.335)\end{array}$ & $\begin{array}{c}1.135^{* * *} \\
(0.341)\end{array}$ & $\begin{array}{l}-0.028 \\
(0.274)\end{array}$ \\
\hline TxDOT expenditures (in $\$ 1,000,000)_{l t}$ & & & & & & $\begin{array}{l}-0.004 \\
(0.004)\end{array}$ & \\
\hline Average house value $_{l t}$ & & & & & & & $\begin{array}{c}0.010 * * \\
(0.005)\end{array}$ \\
\hline Border county effects $_{l t}$ & Yes & Yes & Yes & Yes & Yes & Yes & Yes \\
\hline Number of entrants & 395 & 395 & 395 & 395 & 395 & 395 & 395 \\
\hline Number of tratcs & 4,302 & 4,302 & 4,302 & 4,302 & 4,302 & 4,302 & 4,302 \\
\hline Log likelihood & $-3,180.000$ & $-3,157.000$ & $-3,165.000$ & $-3,149.000$ & $-3,137.000$ & $-3,141.000$ & $-3,155.000$ \\
\hline$\chi^{2}$ & 249.100 & 293.100 & 280.600 & 312.500 & 336.400 & 327.400 & 298.900 \\
\hline
\end{tabular}


Table 9: Models of aggregate entry counts

\begin{tabular}{|c|c|c|c|c|c|c|c|}
\hline \multirow[t]{2}{*}{ Variable } & \multicolumn{7}{|c|}{ Number of entrants } \\
\hline & $(1)$ & $(2)$ & $(3)$ & $(4)$ & $(5)$ & $(6)$ & $(7)$ \\
\hline \multirow{4}{*}{$\begin{array}{l}\text { Number of environmental remediation } \\
\text { incumbents }_{l t} \\
\text { Number of TRI type incumbents } i l t\end{array}$} & $1.048^{* * *}$ & $1.008^{* * *}$ & $1.027^{* * *}$ & $0.980^{* * *}$ & $0.960^{* * *}$ & $0.990^{* * *}$ & $1.019^{* * *}$ \\
\hline & $(0.059)$ & $(0.063)$ & $(0.062)$ & $(0.065)$ & $(0.067)$ & $(0.063)$ & $(0.065)$ \\
\hline & $0.008^{* * *}$ & $0.006^{* * *}$ & $0.005^{* * *}$ & $0.005^{* * *}$ & $0.004^{* *}$ & $0.008^{* * *}$ & $0.004^{* *}$ \\
\hline & $(0.001)$ & $(0.001)$ & $(0.001)$ & $(0.001)$ & $(0.002)$ & $(0.001)$ & $(0.002)$ \\
\hline \multirow[t]{2}{*}{ Median income $\$ 0-\$ 66,700_{l t}$} & & $0.160^{* * *}$ & & $0.265^{* * *}$ & $0.391^{* * *}$ & $0.376^{* * *}$ & \\
\hline & & $(0.045)$ & & $(0.059)$ & $(0.062)$ & $(0.063)$ & \\
\hline \multirow[t]{2}{*}{ Median income $>\$ 66,700-\$ 100,000_{l t}$} & & -0.084 & & 0.001 & 0.088 & 0.077 & \\
\hline & & $(0.096)$ & & $(0.106)$ & $(0.107)$ & $(0.107)$ & \\
\hline \multirow[t]{2}{*}{ Median income $>\$ 100,000_{l t}$} & & 0.001 & & 0.005 & -0.001 & 0.015 & \\
\hline & & $(0.087)$ & & $(0.085)$ & $(0.083)$ & $(0.083)$ & \\
\hline \multirow[t]{2}{*}{ Average wage (in $\$ 10,000)_{l t}$} & & $0.013^{* * *}$ & $0.016^{* * *}$ & $0.015^{* * *}$ & $0.013^{* * *}$ & $0.014^{* * *}$ & $0.014^{* * *}$ \\
\hline & & $(0.004)$ & $(0.003)$ & $(0.003)$ & $(0.004)$ & $(0.004)$ & $(0.003)$ \\
\hline \multirow[t]{2}{*}{ College ratio $_{l t}$} & & & 0.080 & $-3.326^{* *}$ & $-5.050 * * *$ & $-5.307 * * *$ & -0.454 \\
\hline & & & $(0.761)$ & $(1.378)$ & $(1.392)$ & $(1.408)$ & $(0.942)$ \\
\hline \multirow[t]{2}{*}{ Number of amenity establishments $_{l t}$} & & & & $0.004^{* * *}$ & $0.003^{* * *}$ & $0.003^{* * *}$ & $0.003^{* * *}$ \\
\hline & & & & $(0.001)$ & $(0.001)$ & $(0.001)$ & $(0.001)$ \\
\hline \multirow[t]{2}{*}{ Number of roads ${ }_{l t}$} & & 0.004 & 0.002 & 0.003 & 0.006 & & 0.004 \\
\hline & & $(0.004)$ & $(0.004)$ & $(0.004)$ & $(0.004)$ & & $(0.004)$ \\
\hline \multirow[t]{2}{*}{ Number of rail roads $l t$} & & $0.019^{*}$ & $0.018^{*}$ & $0.017^{*}$ & $0.019^{*}$ & & $0.020^{*}$ \\
\hline & & $(0.010)$ & $(0.010)$ & $(0.010)$ & $(0.011)$ & & $(0.010)$ \\
\hline \multirow[t]{2}{*}{ 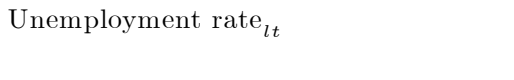 } & & & & & 0.013 & 0.013 & 0.021 \\
\hline & & & & & $(0.013)$ & $(0.014)$ & $(0.018)$ \\
\hline \multirow[t]{2}{*}{ Population (in 1,000$)_{l t}$} & & $0.052^{* * *}$ & $0.068^{* * *}$ & $0.041^{* * *}$ & $0.038 * *$ & $0.044^{* * *}$ & $0.067^{* * *}$ \\
\hline & & $(0.015)$ & $(0.013)$ & $(0.016)$ & $(0.015)$ & $(0.014)$ & $(0.014)$ \\
\hline \multirow[t]{2}{*}{ Land area (in 100 in square miles) $l t$} & & & & & -0.052 & -0.023 & -0.076 \\
\hline & & & & & $(0.039)$ & $(0.030)$ & $(0.049)$ \\
\hline \multirow[t]{2}{*}{ Housing rental ratio $_{l t}$} & & & & & $1.211^{* * *}$ & $1.135^{* * *}$ & -0.027 \\
\hline & & & & & $(0.367)$ & $(0.373)$ & $(0.327)$ \\
\hline \multirow[t]{2}{*}{ TxDOT expenditures (in $\$ 1,000,000)_{l t}$} & & & & & & -0.004 & \\
\hline & & & & & & $(0.004)$ & \\
\hline \multirow[t]{2}{*}{ Average house value $_{l t}$} & & & & & & & $0.010^{* *}$ \\
\hline & & & & & & & $(0.004)$ \\
\hline \multirow{2}{*}{$\begin{array}{l}\text { Border county effects } \\
\text { Year effects }\end{array}$} & Yes & Yes & Yes & Yes & Yes & Yes & Yes \\
\hline & Yes & Yes & Yes & Yes & Yes & Yes & Yes \\
\hline Number of obs. & 30,114 & 30,114 & 30,114 & 30,114 & 30,114 & 30,114 & 30,114 \\
\hline Log likelihood & $-1,987.000$ & $-1,964.000$ & $-1,972.000$ & $-1,956.000$ & $-1,944.000$ & $-1,948.000$ & $-1,962.000$ \\
\hline
\end{tabular}


Table 10: Summary statistics for randomly chosen non-overlapping locations

\begin{tabular}{lc}
\hline Variable & Non-overlapping locations \\
\hline Number of non-overlapping locations & 8,142 \\
Number of environmental remediation entrants & 231 \\
& \\
Average number of environmental remediation entrants & \\
& 0.004 \\
Average number of environmental remediation incumbents & $(0.072)$ \\
& 0.024 \\
Average number of TRI type firms & $(0.173)$ \\
& 1.212 \\
\hline
\end{tabular}

Standard deviation are in parentheses. 
Table 11: Aggregate entry counts at a random location

\begin{tabular}{|c|c|c|c|}
\hline \multirow[t]{2}{*}{ Variable } & \multicolumn{3}{|c|}{ Number of entrants } \\
\hline & $(1)$ & $(2)$ & $(3)$ \\
\hline Number of environmental remediation & $1.142^{* * *}$ & $1.083^{* * *}$ & $1.138^{* * *}$ \\
\hline incumbents within $0-1$ mile $_{l t}$ & $(0.117)$ & $(0.116)$ & $(0.117)$ \\
\hline \multirow[t]{2}{*}{ Number of TRI incumbents within $0-1$ mile $_{l t}$} & $0.012^{* * *}$ & $0.011^{* * *}$ & $0.012^{* * *}$ \\
\hline & $(0.002)$ & $(0.002)$ & $(0.002)$ \\
\hline \multirow[t]{2}{*}{ Median income $\$ 0-\$ 66,700_{l t}$} & $0.407^{* * *}$ & $0.309 * * *$ & \\
\hline & $(0.084)$ & $(0.087)$ & \\
\hline \multirow[t]{2}{*}{ Median income $>\$ 66,700-\$ 100,000_{l t}$} & $0.254^{* *}$ & 0.193 & \\
\hline & $(0.128)$ & $(0.127)$ & \\
\hline \multirow[t]{2}{*}{ Median income $>\$ 100,000_{l t}$} & -0.075 & -0.079 & \\
\hline & $(0.244)$ & $(0.242)$ & \\
\hline \multirow[t]{2}{*}{ Average wage $(\text { in } \$ 10,000)_{l t}$} & $0.023^{* * *}$ & $0.022^{* * *}$ & $0.022^{* * *}$ \\
\hline & $(0.008)$ & $(0.008)$ & $(0.007)$ \\
\hline \multirow[t]{2}{*}{ College ratio $_{l t}$} & -1.753 & -1.038 & $2.544^{*}$ \\
\hline & $(1.595)$ & $(1.617)$ & $(1.304)$ \\
\hline \multirow[t]{2}{*}{ Number of amenity establishments ${ }_{l t}$} & $0.004^{* * *}$ & $0.003^{* *}$ & $0.004^{* * *}$ \\
\hline & $(0.001)$ & $(0.001)$ & $(0.001)$ \\
\hline \multirow[t]{2}{*}{ Number of roads $_{l t}$} & -0.009 & & -0.009 \\
\hline & $(0.006)$ & & $(0.006)$ \\
\hline \multirow[t]{2}{*}{ Number of rail roads $s_{l t}$} & 0.013 & & 0.015 \\
\hline & $(0.012)$ & & $(0.011)$ \\
\hline \multirow[t]{2}{*}{ 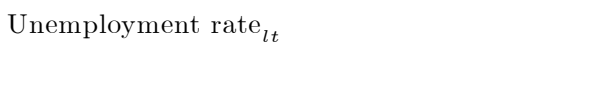 } & $0.066^{* * *}$ & $0.065^{* * *}$ & $0.075^{* * *}$ \\
\hline & $(0.014)$ & $(0.014)$ & $(0.015)$ \\
\hline \multirow[t]{2}{*}{ Population (in 1,000$)_{l t}$} & -0.009 & 0.002 & $0.030^{*}$ \\
\hline & $(0.018)$ & $(0.017)$ & $(0.017)$ \\
\hline \multirow[t]{2}{*}{ Housing rental ratio ${ }_{l t}$} & $4.430^{* * *}$ & $3.799^{* * *}$ & $3.307^{* * *}$ \\
\hline & $(0.322)$ & $(0.367)$ & $(0.313)$ \\
\hline \multirow[t]{2}{*}{ TxDOT expenditures (in $\$ 1,000,000)_{l t}$} & & $-0.030^{* *}$ & \\
\hline & & $(0.012)$ & \\
\hline \multirow[t]{2}{*}{ Average house value $_{l t}$} & & & $0.020^{* * *}$ \\
\hline & & & $(0.007)$ \\
\hline Border county effects $_{l t}$ & Yes & Yes & Yes \\
\hline Year effects & Yes & Yes & Yes \\
\hline Number of obs. & 56,994 & 56,994 & 56,994 \\
\hline Log likelihood & $-1,364.000$ & $-1,351.000$ & $-1,378.000$ \\
\hline
\end{tabular}


Table 12: Exit patterns

\begin{tabular}{|c|c|c|c|c|c|c|c|c|c|}
\hline \multirow[t]{2}{*}{ Entry year } & \multirow{2}{*}{$\begin{array}{c}\text { Total } \\
\text { entrants }\end{array}$} & \multicolumn{7}{|c|}{ Exit year } & \multirow[t]{2}{*}{ Total } \\
\hline & & 2000 & 2001 & 2002 & 2003 & 2004 & 2005 & 2006 & \\
\hline 2000 & 43 & 0 & 2 & 2 & 5 & 6 & 3 & 2 & 20 \\
\hline 2001 & 47 & & 5 & 6 & 16 & 6 & 3 & 3 & 39 \\
\hline 2002 & 98 & & & 4 & 29 & 18 & 11 & 7 & 69 \\
\hline 2003 & 54 & & & & 7 & 11 & 10 & 5 & 33 \\
\hline 2004 & 58 & & & & & 13 & 10 & 9 & 33 \\
\hline 2005 & 50 & & & & & & 9 & 7 & 16 \\
\hline 2006 & 45 & & & & & & & 5 & 5 \\
\hline Total & 395 & 0 & 7 & 12 & 57 & 54 & 46 & 38 & 214 \\
\hline
\end{tabular}

Table 13: Establishment level summary statistics for exit

\begin{tabular}{lc}
\hline Variable & Mean (Standard deviation) \\
\hline Establishments with past experience & 0.364 \\
& $(0.481)$ \\
Average number of branches & 1.021 \\
& $(2.334)$ \\
Age (in months) & 42.702 \\
& $(22.532)$ \\
Average wage (in \$10,000) & 4.908 \\
Size & $(11.619)$ \\
& 18.872 \\
\hline
\end{tabular}


Table 14: Logit results for exit

\begin{tabular}{|c|c|c|c|c|c|c|}
\hline \multirow[t]{2}{*}{ Variable } & \multicolumn{6}{|c|}{ Exit } \\
\hline & (1) & $(2)$ & $(3)$ & $(4)$ & $(5)$ & $(6)$ \\
\hline Number of environmental remediation & $0.076^{* * *}$ & $0.075^{* * *}$ & $0.077^{* * *}$ & $0.078^{* * *}$ & $0.078^{* * *}$ & $0.078^{* * *}$ \\
\hline incumbents $i l t$ & $(0.010)$ & $(0.010)$ & $(0.010)$ & $(0.010)$ & $(0.010)$ & $(0.010)$ \\
\hline \multirow[t]{2}{*}{ Number of TRI type incumbents $i l t$} & -0.000 & -0.000 & -0.000 & -0.000 & -0.000 & -0.000 \\
\hline & $(0.000)$ & $(0.000)$ & $(0.000)$ & $(0.000)$ & $(0.000)$ & $(0.000)$ \\
\hline \multirow[t]{2}{*}{ Establishments with past experience $_{i}$} & -0.016 & -0.017 & -0.016 & -0.017 & -0.018 & -0.018 \\
\hline & $(0.019)$ & $(0.019)$ & $(0.019)$ & $(0.019)$ & $(0.019)$ & $(0.019)$ \\
\hline \multirow[t]{2}{*}{ Number of branchesit } & -0.002 & -0.002 & -0.002 & -0.001 & -0.001 & -0.001 \\
\hline & $(0.004)$ & $(0.004)$ & $(0.004)$ & $(0.004)$ & $(0.004)$ & $(0.004)$ \\
\hline \multirow[t]{2}{*}{ Age $_{i t}$} & $-0.008^{* * *}$ & $-0.008^{* * *}$ & $-0.008^{* * *}$ & $-0.008^{* * *}$ & $-0.008^{* * *}$ & $-0.008^{* * *}$ \\
\hline & $(0.001)$ & $(0.001)$ & $(0.001)$ & $(0.001)$ & $(0.001)$ & $(0.001)$ \\
\hline \multirow[t]{2}{*}{ Median income $\$ 0-\$ 66,700_{l t}$} & -0.005 & & -0.006 & 0.006 & 0.006 & \\
\hline & $(0.007)$ & & $(0.009)$ & $(0.011)$ & $(0.011)$ & \\
\hline \multirow{2}{*}{ Median income $>\$ 66,700-\$ 100,000_{l t}$} & -0.003 & & -0.003 & 0.003 & 0.005 & \\
\hline & $(0.013)$ & & $(0.014)$ & $(0.014)$ & $(0.015)$ & \\
\hline \multirow{2}{*}{ Median income $>\$ 100,000_{l t}$} & 0.015 & & 0.015 & 0.016 & 0.016 & \\
\hline & $(0.012)$ & & $(0.012)$ & $(0.012)$ & $(0.012)$ & \\
\hline \multirow[t]{2}{*}{ Average wage (in $\$ 10,000)_{l t}$} & -0.003 & -0.003 & -0.003 & -0.002 & -0.003 & -0.003 \\
\hline & $(0.002)$ & $(0.002)$ & $(0.002)$ & $(0.002)$ & $(0.002)$ & $(0.002)$ \\
\hline \multirow[t]{2}{*}{ Size $_{i t}$} & $-0.001 * *$ & $-0.001 * *$ & $-0.001 * *$ & $-0.001 * *$ & $-0.001 * *$ & $-0.001 * *$ \\
\hline & $(0.000)$ & $(0.000)$ & $(0.000)$ & $(0.000)$ & $(0.000)$ & $(0.000)$ \\
\hline \multirow[t]{2}{*}{ College ratio $l t$} & & -0.016 & 0.019 & -0.204 & -0.190 & -0.260 \\
\hline & & $(0.128)$ & $(0.171)$ & $(0.211)$ & $(0.209)$ & $(0.200)$ \\
\hline \multirow[t]{2}{*}{ Number of amenity establishments $\mathrm{s}_{l t}$} & & & -0.000 & -0.000 & -0.000 & -0.000 \\
\hline & & & $(0.000)$ & $(0.000)$ & $(0.000)$ & $(0.000)$ \\
\hline \multirow[t]{2}{*}{ Number of roads $s_{l t}$} & -0.000 & -0.000 & -0.000 & -0.000 & & -0.000 \\
\hline & $(0.001)$ & $(0.001)$ & $(0.001)$ & $(0.001)$ & & $(0.001)$ \\
\hline \multirow[t]{2}{*}{ Number of rail roads $_{l t}$} & -0.002 & -0.002 & -0.002 & -0.001 & & -0.001 \\
\hline & $(0.001)$ & $(0.001)$ & $(0.001)$ & $(0.001)$ & & $(0.001)$ \\
\hline \multirow[t]{2}{*}{ 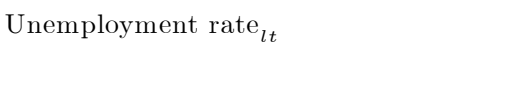 } & & & & -0.002 & -0.002 & -0.002 \\
\hline & & & & $(0.003)$ & $(0.003)$ & $(0.003)$ \\
\hline \multirow[t]{2}{*}{ Population (in 1,000$)_{l t}$} & 0.002 & 0.001 & 0.002 & 0.001 & 0.001 & 0.001 \\
\hline & (0.003) & $(0.003)$ & (0.003) & $(0.003)$ & (0.003) & (0.003) \\
\hline \multirow[t]{2}{*}{ Land area (in 100 in square miles) ${ }_{l t}$} & & & & -0.009 & -0.014 & -0.009 \\
\hline & & & & $(0.011)$ & $(0.012)$ & $(0.011)$ \\
\hline \multirow[t]{2}{*}{ Housing rental ratio $_{l t}$} & & & & 0.090 & $0.098^{*}$ & $0.106^{*}$ \\
\hline & & & & $(0.056)$ & $(0.058)$ & $(0.054)$ \\
\hline \multirow[t]{2}{*}{ MSA } & -0.005 & -0.008 & -0.004 & -0.017 & -0.001 & -0.019 \\
\hline & $(0.036)$ & $(0.036)$ & $(0.036)$ & $(0.039)$ & $(0.047)$ & $(0.039)$ \\
\hline \multirow[t]{2}{*}{ TxDOT expenditures (in $\$ 1,000,000)_{l t}$} & & & & & 0.001 & \\
\hline & & & & & $(0.001)$ & \\
\hline \multirow[t]{2}{*}{ Average house value $_{l t}$} & & & & & & 0.003 \\
\hline & & & & & & $(0.002)$ \\
\hline Border county effects $s_{l t}$ & Yes & Yes & Yes & Yes & Yes & Yes \\
\hline Year effects & Yes & Yes & Yes & Yes & Yes & Yes \\
\hline Number of Observations & 1,346 & 1,346 & 1,346 & 1,346 & 1,346 & 1,346 \\
\hline Log likelihood & -420.972 & -422.477 & -420.822 & -419.178 & -419.228 & -419.759 \\
\hline
\end{tabular}




\section{Appendix}

\section{Figures and Tables}

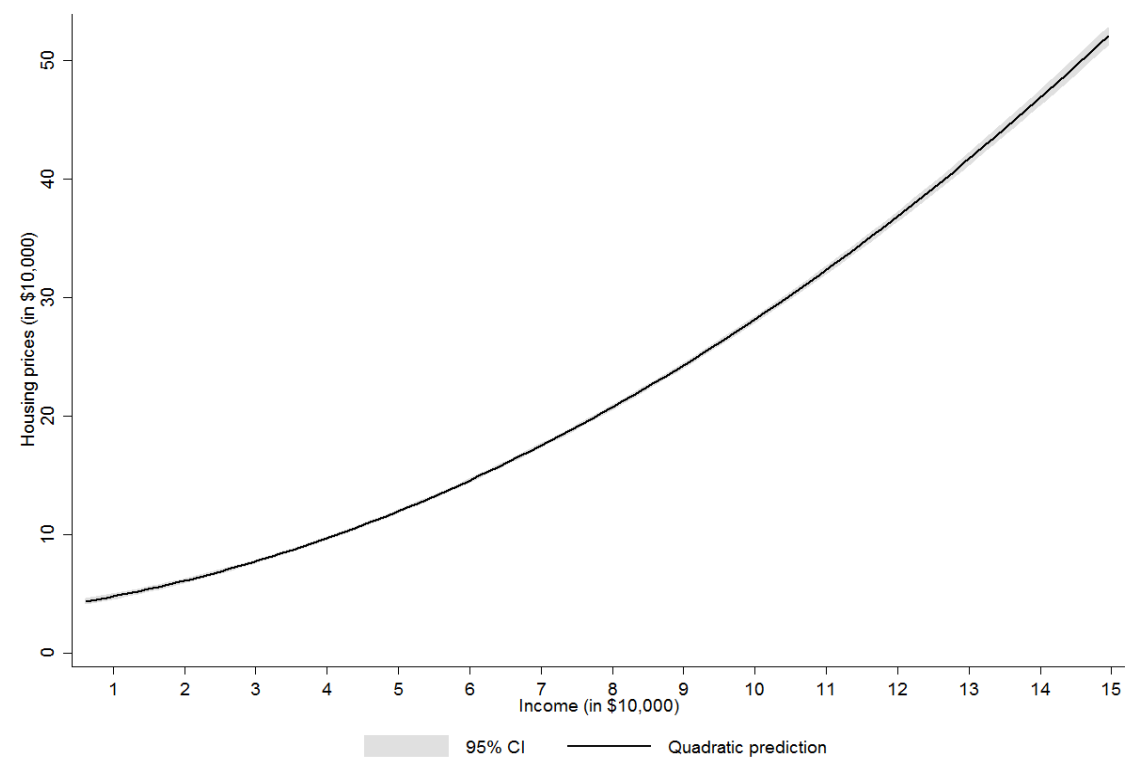

Panel A

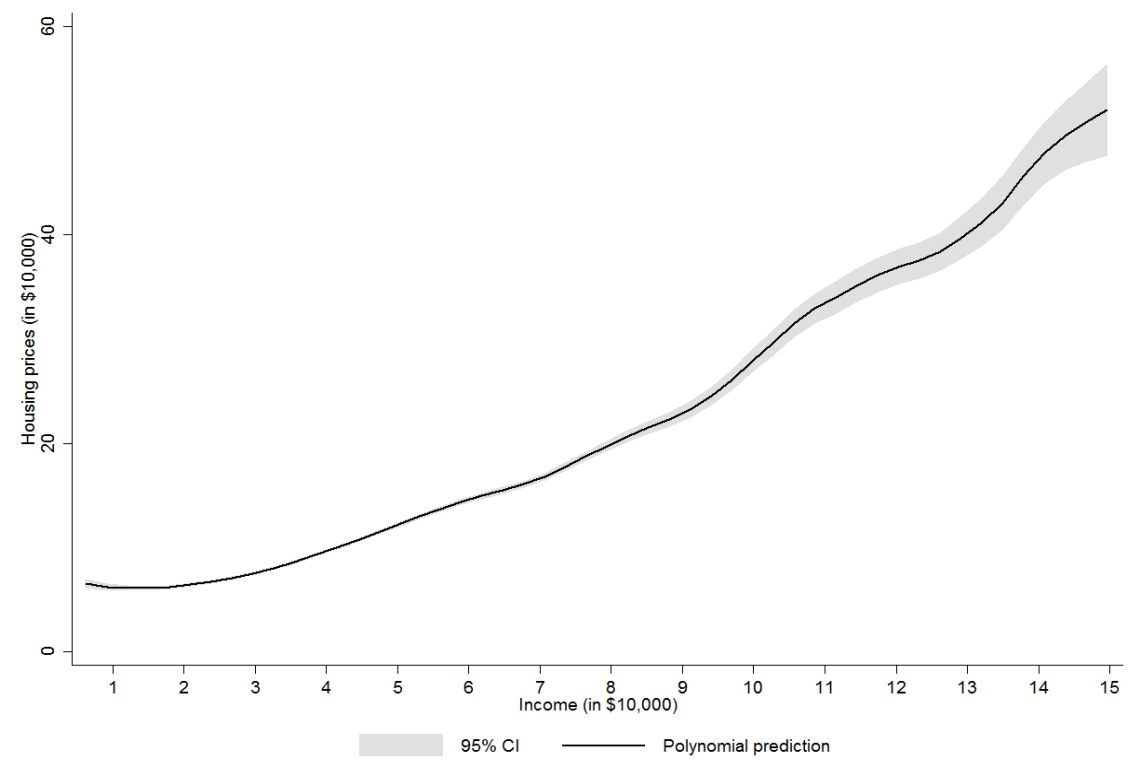

Panel B

Figure 1: Relationship between 48 using prices and median income 
Table A.1: Variable Descriptions

\begin{tabular}{|c|c|}
\hline Variable & Description \\
\hline Number of environmental remediation & Number of environmental remediation per tract per year. \\
\hline firms $l t$ & NAICS codes: $562112,562211,562910$, and 562920 \\
\hline TRI type establishments $l t$ & Number of TRI type firms per tract per year. \\
\hline Tract-level toxicity (in pounds) & $\begin{array}{l}\text { The EPA provides toxicity weights for each chemical reported in the TRI which } \\
\text { allows for aggreating heterogeneous releases. We then aggregate total release per } \\
\text { tract for a given year. }\end{array}$ \\
\hline Age $_{i t}$ & Establishment's age in months \\
\hline Number of employees $i t$ & Establishment or tract level number of employees per year. \\
\hline Employement ratio $i t$ & $\begin{array}{l}\text { This is the establishment's employment divided by the total employees in the } \\
\text { industry in TX at a given year. }\end{array}$ \\
\hline Wage $_{i t}$ & Establishment level wage per year. \\
\hline Plant with past experience $i$ & This is a plant with past experience in the industry \\
\hline Number of branches in $\mathrm{TX}_{i t}$ & Number of branches in TX \\
\hline Number of roads $l t$ & $\begin{array}{l}\text { We use the U.S. Census Bureau's Census Feature Class Codes (CFCC) to identify } \\
\text { roads. These road maps are provided by ESRI Data \& Maps (2000) at census tract } \\
\text { level. We use all major highways to small roads that provide access to businesses, } \\
\text { facilities, and rest areas along limited-access highways. }\end{array}$ \\
\hline Number of rail roads ${ }_{l t}$ & $\begin{array}{l}\text { As in roads we use the U.S. Census Bureau's Census Feature Class Codes (CFCC) } \\
\text { and ESRI Data \& Maps (2000) to identify rail roads. We use all major and minor } \\
\text { rail tracks identified by ESRI Data \& Maps. }\end{array}$ \\
\hline Median income $(\$)_{l t}$ & Census tract level median income. \\
\hline Poverty ratiolt & Census tract level percentage of the population under the poverty rate. \\
\hline College ratio $l t$ & Census tract level college graduates as percentage of the population. \\
\hline Number of amenity establishments $l t$ & $\begin{array}{l}\text { To measure the relative local presence of amenities, we compute the tract level } \\
\text { number of establishments in NAICS 71, Arts, Entertainment, and Recreation, } \\
\text { and NAICS } 721110 \text { (hotels and motels), } 722110 \text { (full service restaurants), and } \\
722410 \text { (drinking places, alcoholic beverages) as reported in the QCEW data. }\end{array}$ \\
\hline Housing rental ratio $l t$ & Tract level percentage of housing stock rented. \\
\hline Unemployment rate $_{l t}$ & Census tract level unemploymentrate. \\
\hline Population $_{l t}$ & Census tract level total population. \\
\hline TxDOT expenditures $_{l t}($ in $\$ 1,000,000)$ & $\begin{array}{l}\text { We construct tract level road construction expenditures by weighting county totals } \\
\text { by tact level population. }\end{array}$ \\
\hline Average house value $_{l t}$ & Census tract level average house value. \\
\hline Percent nonwhite residents & Census tract-level share of nonwhite population per year. \\
\hline
\end{tabular}


Table A.2: Explaining Variation in Toxic Pounds, TRI Type Firms, and Remediation Firms

\begin{tabular}{|c|c|c|c|c|}
\hline \multirow[t]{3}{*}{ Variable } & \multirow{3}{*}{$\begin{array}{c}\text { Toxicity } \\
\text { in pounds } l t \\
(1)\end{array}$} & \multicolumn{3}{|c|}{ Number of firms in } \\
\hline & & \multirow{2}{*}{$\frac{\text { TRI type } l t}{(2)}$} & \multicolumn{2}{|c|}{ Remediation $l t$} \\
\hline & & & $(3)$ & $(4)$ \\
\hline \multirow[t]{2}{*}{ Median income (in $\$ 10,000)_{l t}$} & $0.792^{* * *}$ & $1.302^{* * *}$ & $0.517^{* * *}$ & $0.450^{* * *}$ \\
\hline & $(0.127)$ & $(0.138)$ & $(0.088)$ & $(0.085)$ \\
\hline \multirow{2}{*}{ Median income (in $\$ 10,000)_{l t}^{2}$} & $-0.076^{* * *}$ & $-0.093^{* * *}$ & $-0.034^{* * *}$ & $-0.030^{* * *}$ \\
\hline & $(0.016)$ & $(0.019)$ & $(0.011)$ & $(0.010)$ \\
\hline \multirow[t]{2}{*}{ Median income (in $\$ 10,000)_{l t}^{3}$} & $0.002^{* * *}$ & $0.002^{* * *}$ & $0.001^{*}$ & $0.001^{*}$ \\
\hline & $(0.001)$ & $(0.001)$ & $(0.000)$ & $(0.000)$ \\
\hline \multirow{2}{*}{ Number of TRI type incumbent establishments $_{l t}$} & & & & $0.027^{* * *}$ \\
\hline & & & & $(0.005)$ \\
\hline \multirow[t]{2}{*}{ Percentage nonwhite residents $_{l t}$} & $1.028^{* * *}$ & $2.760 * * *$ & 0.018 & -0.178 \\
\hline & $(0.191)$ & $(0.532)$ & $(0.199)$ & $(0.198)$ \\
\hline \multirow{2}{*}{ Average wage (in $\$ 10,000)_{l t}$} & $0.033^{* * *}$ & $0.077 * * *$ & $0.024^{* * *}$ & $0.021^{* * *}$ \\
\hline & $(0.006)$ & $(0.012)$ & $(0.004)$ & $(0.004)$ \\
\hline \multirow[t]{2}{*}{ College ratio $_{l t}$} & $-5.325^{* * *}$ & $-8.741 * * *$ & $-3.978 * * *$ & $-3.543^{* * *}$ \\
\hline & $(0.916)$ & $(0.988)$ & $(0.648)$ & $(0.633)$ \\
\hline \multirow{2}{*}{ Number of amenity establishments ${ }_{l t}$} & $-0.007^{*}$ & $0.111^{* * *}$ & $0.011 * * *$ & $0.007^{* * *}$ \\
\hline & $(0.003)$ & $(0.014)$ & $(0.001)$ & $(0.001)$ \\
\hline \multirow[t]{2}{*}{ Number of roads $s_{l t}$} & $0.015^{* * *}$ & $0.171^{* * *}$ & $0.024^{* * *}$ & $0.015^{* * *}$ \\
\hline & $(0.002)$ & $(0.025)$ & $(0.002)$ & $(0.003)$ \\
\hline \multirow[t]{2}{*}{ Number of rail roads ${ }_{l t}$} & $0.072^{* * *}$ & $0.400^{* * *}$ & $0.058^{* * *}$ & $0.043^{* * *}$ \\
\hline & $(0.009)$ & $(0.037)$ & $(0.006)$ & $(0.006)$ \\
\hline \multirow[t]{2}{*}{ 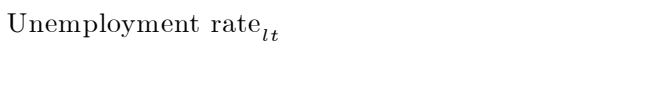 } & $0.014^{* * *}$ & -0.005 & $0.021^{* * *}$ & $0.023^{* * *}$ \\
\hline & $(0.005)$ & $(0.017)$ & $(0.007)$ & $(0.007)$ \\
\hline \multirow[t]{2}{*}{ Population (in 1,000$)_{l t}$} & -0.001 & $0.106^{* * *}$ & $0.034^{* * *}$ & $0.032^{* * *}$ \\
\hline & $(0.008)$ & $(0.019)$ & $(0.009)$ & $(0.008)$ \\
\hline \multirow{2}{*}{ Land area (in 100 in square miles) ${ }_{l t}$} & $-0.034^{* * *}$ & $-0.315^{* * *}$ & $-0.110^{* * *}$ & $-0.083^{* * *}$ \\
\hline & $(0.013)$ & $(0.052)$ & $(0.025)$ & $(0.021)$ \\
\hline \multirow[t]{2}{*}{ 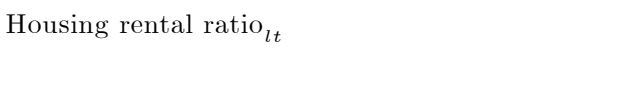 } & -0.070 & $1.591 * * *$ & $1.208^{* * *}$ & $1.120^{* * *}$ \\
\hline & $(0.178)$ & $(0.334)$ & $(0.200)$ & $(0.192)$ \\
\hline \multirow{2}{*}{$\begin{array}{l}\text { Border county effects } \\
\text { Year effects }\end{array}$} & Yes & Yes & Yes & Yes \\
\hline & Yes & Yes & Yes & Yes \\
\hline Number of observations & 30,114 & 30,114 & 30,114 & 30,114 \\
\hline Log likelihood & $-3,283.000$ & $-109,657.000$ & $-9,644.000$ & $-9,516.000$ \\
\hline Uncensored observations & 833 & 29,968 & 2,104 & 2,104 \\
\hline
\end{tabular}


Table A.3: Explaining Variation in Toxic Pounds, TRI Type Firms, and Remediation Firms - alternate specification

\begin{tabular}{|c|c|c|c|c|}
\hline \multirow[t]{3}{*}{ Variable } & \multirow{3}{*}{$\begin{array}{c}\begin{array}{c}\text { Toxicity } \\
\text { in pounds } l t\end{array} \\
(1)\end{array}$} & \multicolumn{3}{|c|}{ Number of firms in } \\
\hline & & \multirow{2}{*}{$\frac{\text { TRI type }_{l t}}{(2)}$} & \multicolumn{2}{|c|}{ Remediation $_{l t}$} \\
\hline & & & (3) & $(4)$ \\
\hline \multirow[t]{2}{*}{ Median income $\$ 0-\$ 66,700_{l t}$} & $0.244^{* * *}$ & $0.621^{* * *}$ & $0.309^{* * *}$ & $0.274^{* * *}$ \\
\hline & $(0.034)$ & $(0.048)$ & $(0.033)$ & $(0.033)$ \\
\hline \multirow{2}{*}{ Median income $>\$ 66,700-\$ 100,000_{l t}$} & -0.017 & 0.047 & -0.041 & -0.051 \\
\hline & $(0.069)$ & $(0.113)$ & $(0.058)$ & $(0.056)$ \\
\hline \multirow[t]{2}{*}{ Median income $>\$ 100,000_{l t}$} & $-0.628^{*}$ & -0.088 & 0.025 & 0.036 \\
\hline & $(0.359)$ & $(0.062)$ & $(0.052)$ & $(0.048)$ \\
\hline \multirow{2}{*}{ Number of TRI type incumbent establishments $_{l t}$} & & & & $0.027^{* * *}$ \\
\hline & & & & $(0.005)$ \\
\hline \multirow[t]{2}{*}{ Percentage nonwhite residents ${ }_{l t}$} & $0.868^{* * *}$ & $2.633^{* * *}$ & 0.046 & -0.141 \\
\hline & $(0.180)$ & $(0.538)$ & $(0.196)$ & $(0.195)$ \\
\hline \multirow[t]{2}{*}{ Average wage (in $\$ 10,000)_{l t}$} & $0.033^{* * *}$ & $0.077^{* * *}$ & $0.024^{* * *}$ & $0.021^{* * *}$ \\
\hline & $(0.006)$ & $(0.012)$ & $(0.004)$ & $(0.004)$ \\
\hline \multirow{2}{*}{ College ratio $_{l t}$} & $-5.735 * * *$ & $-8.845^{* * *}$ & $-4.090 * * *$ & $-3.650 * * *$ \\
\hline & $(0.960)$ & $(1.021)$ & $(0.648)$ & $(0.632)$ \\
\hline \multirow[t]{2}{*}{ Number of amenity establishments $_{l t}$} & $-0.007^{*}$ & $0.111^{* * *}$ & $0.011^{* * *}$ & $0.007^{* * *}$ \\
\hline & $(0.003)$ & $(0.014)$ & $(0.001)$ & $(0.001)$ \\
\hline \multirow[t]{2}{*}{ Number of roads ${ }_{l t}$} & $0.015^{* * *}$ & $0.172^{* * *}$ & $0.024^{* * *}$ & $0.015^{* * *}$ \\
\hline & $(0.002)$ & $(0.025)$ & $(0.002)$ & $(0.003)$ \\
\hline \multirow[t]{2}{*}{ Number of rail roads ${ }_{l t}$} & $0.071^{* * *}$ & $0.398^{* * *}$ & $0.057^{* * *}$ & $0.043^{* * *}$ \\
\hline & $(0.009)$ & $(0.037)$ & $(0.006)$ & $(0.006)$ \\
\hline \multirow[t]{2}{*}{ Unemployment rate $_{l t}$} & $0.012^{* *}$ & -0.012 & $0.020^{* * *}$ & $0.022^{* * *}$ \\
\hline & $(0.005)$ & $(0.017)$ & $(0.007)$ & $(0.007)$ \\
\hline \multirow[t]{2}{*}{ Population (in 1,000$)_{l t}$} & -0.002 & $0.107^{* * *}$ & $0.033^{* * *}$ & $0.031^{* * *}$ \\
\hline & $(0.008)$ & $(0.019)$ & $(0.009)$ & $(0.009)$ \\
\hline \multirow[t]{2}{*}{ Land area (in 100 in square miles) $l_{l t}$} & $-0.031^{* *}$ & $-0.312^{* * *}$ & $-0.107 * * *$ & $-0.081 * * *$ \\
\hline & $(0.012)$ & $(0.052)$ & $(0.024)$ & $(0.021)$ \\
\hline \multirow{2}{*}{ Housing rental ratio $_{l t}$} & -0.028 & $1.580^{* * *}$ & $1.209^{* * *}$ & $1.121^{* * *}$ \\
\hline & $(0.177)$ & $(0.339)$ & $(0.200)$ & $(0.193)$ \\
\hline Border county effects $_{l t}$ & Yes & Yes & Yes & Yes \\
\hline Year effects & Yes & Yes & Yes & Yes \\
\hline Number of observations & 30,114 & 30,114 & 30,114 & 30,114 \\
\hline Log likelihood & $-3,298.000$ & $-109,663.000$ & $-9,636.000$ & $-9,508.000$ \\
\hline Uncensored observations & 833 & 29,968 & 2,104 & 2,104 \\
\hline
\end{tabular}


Table A.4: Explaining Variation in TRI Type Firms (with and without TRI), and Remediation Firms

\begin{tabular}{|c|c|c|c|c|}
\hline \multirow[t]{4}{*}{ Variable } & \multicolumn{4}{|c|}{ Number of firms in } \\
\hline & \multicolumn{3}{|c|}{ TRI type $l t$} & \multirow[t]{2}{*}{ Remediation $_{l t}$} \\
\hline & (without TRI) & MSA & Non-MSA & \\
\hline & $(1)$ & $(2)$ & $(3)$ & (4) \\
\hline Median income $\$ 0-\$ 66,700_{l t}$ & $\begin{array}{c}0.548^{* * *} \\
(0.045)\end{array}$ & $\begin{array}{c}0.359^{* * *} \\
(0.059)\end{array}$ & $\begin{array}{c}0.323^{* * *} \\
(0.066)\end{array}$ & $\begin{array}{c}0.279^{* * *} \\
(0.032)\end{array}$ \\
\hline Median income $>\$ 66,700-\$ 100,000_{l t}$ & $\begin{array}{c}0.107 \\
(0.118)\end{array}$ & $\begin{array}{c}0.099 \\
(0.120)\end{array}$ & $\begin{array}{c}-0.962^{* * *} \\
(0.233)\end{array}$ & $\begin{array}{l}-0.054 \\
(0.056)\end{array}$ \\
\hline Median income $>\$ 100,000_{l t}$ & $\begin{array}{l}-0.091 \\
(0.061)\end{array}$ & $\begin{array}{l}-0.123^{*} \\
(0.066)\end{array}$ & & $\begin{array}{c}0.035 \\
(0.048)\end{array}$ \\
\hline Number of TRI type (without TRI) incumbent establishments $_{l t}$ & & & & $\begin{array}{c}0.026^{* * *} \\
(0.005)\end{array}$ \\
\hline Average wage (in $\$ 10,000)_{l t}$ & $\begin{array}{c}0.077 * * * \\
(0.012)\end{array}$ & $\begin{array}{c}0.071^{* * *} \\
(0.012)\end{array}$ & $\begin{array}{c}0.244^{* * *} \\
(0.070)\end{array}$ & $\begin{array}{c}0.021^{* * *} \\
(0.004)\end{array}$ \\
\hline College ratio $_{l t}$ & $\begin{array}{c}-10.191^{* * *} \\
(0.916)\end{array}$ & $\begin{array}{c}-8.663^{* * *} \\
(1.097)\end{array}$ & $\begin{array}{c}1.950 \\
(1.677)\end{array}$ & $\begin{array}{c}-3.585^{* * *} \\
(0.626)\end{array}$ \\
\hline Number of amenity establishments ${ }_{l t}$ & $\begin{array}{c}0.110^{* * *} \\
(0.013)\end{array}$ & $\begin{array}{c}0.105^{* * *} \\
(0.013)\end{array}$ & $\begin{array}{c}0.110^{* * *} \\
(0.011)\end{array}$ & $\begin{array}{c}0.007^{* * * *} \\
(0.001)\end{array}$ \\
\hline Number of roads ${ }_{l t}$ & $\begin{array}{c}0.168^{* * *} \\
(0.025)\end{array}$ & $\begin{array}{c}0.210^{* * *} \\
(0.032)\end{array}$ & $\begin{array}{c}0.041^{* * *} \\
(0.004)\end{array}$ & $\begin{array}{c}0.015^{* * *} \\
(0.003)\end{array}$ \\
\hline Number of rail roads ${ }_{l t}$ & $\begin{array}{c}0.388^{* * * *} \\
(0.038)\end{array}$ & $\begin{array}{c}0.484^{* * *} \\
(0.050)\end{array}$ & $\begin{array}{c}0.130 * * * \\
(0.012)\end{array}$ & $\begin{array}{c}0.044^{* * *} \\
(0.006)\end{array}$ \\
\hline Unemployment rate $_{l t}$ & $\begin{array}{c}0.004 \\
(0.016)\end{array}$ & $\begin{array}{l}-0.019 \\
(0.020)\end{array}$ & $\begin{array}{l}-0.028^{*} \\
(0.014)\end{array}$ & $\begin{array}{c}0.022^{* * *} \\
(0.007)\end{array}$ \\
\hline Population (in 1,000$)_{l t}$ & $\begin{array}{c}0.116^{* * *} \\
(0.019)\end{array}$ & $\begin{array}{c}0.092^{* * *} \\
(0.021)\end{array}$ & $\begin{array}{c}0.308^{* * *} \\
(0.022)\end{array}$ & $\begin{array}{c}0.031^{* * *} \\
(0.009)\end{array}$ \\
\hline Land area (in 100 in square miles) $l t$ & $\begin{array}{c}-0.328^{* * *} \\
(0.055)\end{array}$ & $\begin{array}{c}-0.518^{* * *} \\
(0.149)\end{array}$ & $\begin{array}{c}-0.041^{* * *} \\
(0.011)\end{array}$ & $\begin{array}{c}-0.080^{* * *} \\
(0.020)\end{array}$ \\
\hline Housing rental ratio ${ }_{l t}$ & $\begin{array}{c}2.671^{* * *} \\
(0.357)\end{array}$ & $\begin{array}{c}1.598 * * * \\
(0.424)\end{array}$ & $\begin{array}{c}1.818^{* * *} \\
(0.506)\end{array}$ & $\begin{array}{c}1.067^{* * *} \\
(0.176)\end{array}$ \\
\hline Border county effects $_{l t}$ & Yes & Yes & Yes & Yes \\
\hline Year effects & Yes & Yes & Yes & Yes \\
\hline Number of observations & 30,114 & 24,654 & 5,460 & 30,114 \\
\hline Log likelihood & $-109,629$ & $-91,844$ & $-13,111$ & $-9,511$ \\
\hline Uncensored observations & 29,968 & 24,534 & 5,434 & 2,104 \\
\hline
\end{tabular}

Robust standard errors are in parentheses. ${ }^{* * *} \mathrm{p}<0.01,{ }^{* *} \mathrm{p}<0.05,{ }^{*} \mathrm{p}<0.1$ 
Table A.5: Explaining Variation of Non-TRI Type Firms

\begin{tabular}{|c|c|c|c|c|}
\hline \multirow{2}{*}{\multicolumn{3}{|c|}{ Variable }} & $\mathrm{Nu}$ & mber of firms $l t$ \\
\hline & & & & $(1)$ \\
\hline \multicolumn{3}{|c|}{ Median income $\$ 0-\$ 66,700_{l t}$} & & $\begin{array}{l}0.910^{* * *} \\
(0.088)\end{array}$ \\
\hline \multicolumn{3}{|c|}{ Median income $>\$ 66,700-\$ 100,000_{l t}$} & & $\begin{array}{c}1.561^{* * *} \\
(0.161)\end{array}$ \\
\hline \multicolumn{3}{|c|}{ Median income $>\$ 100,000_{l t}$} & & $\begin{array}{c}0.006 \\
(0.135)\end{array}$ \\
\hline \multicolumn{3}{|c|}{ Average wage (in $\$ 10,000)_{l t}$} & & $\begin{array}{c}0.161^{* * *} \\
(0.024)\end{array}$ \\
\hline \multicolumn{3}{|l|}{ College ratio $_{l t}$} & & $\begin{array}{c}33.129 * * * \\
(2.359)\end{array}$ \\
\hline \multicolumn{3}{|c|}{ Number of amenity establishments ${ }_{l t}$} & & $\begin{array}{c}0.362^{* * *} \\
(0.053)\end{array}$ \\
\hline \multicolumn{3}{|c|}{ Number of roads $s_{l t}$} & & $\begin{array}{c}0.239^{* * *} \\
(0.018)\end{array}$ \\
\hline \multicolumn{3}{|c|}{ Number of rail roads $_{l t}$} & & $\begin{array}{c}0.051^{* *} \\
(0.023)\end{array}$ \\
\hline \multicolumn{3}{|c|}{ 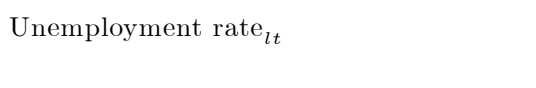 } & & $\begin{array}{c}0.092^{* *} \\
(0.038)\end{array}$ \\
\hline \multicolumn{3}{|c|}{ Population (in 1,000$)_{l t}$} & & $\begin{array}{c}0.884^{* * *} \\
(0.037)\end{array}$ \\
\hline \multicolumn{3}{|c|}{ Land area (in 100 in square miles) ${ }_{l t}$} & & $\begin{array}{c}-0.287^{* * *} \\
(0.044)\end{array}$ \\
\hline \multicolumn{3}{|c|}{ Housing rental ratio ${ }_{l t}$} & & $\begin{array}{c}15.099 * * * \\
(0.636)\end{array}$ \\
\hline \multirow{2}{*}{\multicolumn{3}{|c|}{$\begin{array}{l}\text { Border county effects } \\
\text { Year effects }\end{array}$}} & & Yes \\
\hline & & & & Yes \\
\hline \multicolumn{3}{|c|}{ Number of observations } & & 30,114 \\
\hline \multicolumn{3}{|c|}{ Log likelihood } & & $-113,216.000$ \\
\hline \multicolumn{3}{|c|}{ Uncensored observations } & & 0 \\
\hline \multicolumn{5}{|c|}{ Robust standard errors are in parentheses. ${ }^{* * *} \mathrm{p}<0.01,{ }^{* *} \mathrm{p}<0.05,{ }^{*}$} \\
\hline \multicolumn{5}{|c|}{ Table A.6: Tract ranking } \\
\hline \multirow{2}{*}{\multicolumn{2}{|c|}{ Variable }} & & 2006 & \\
\hline & & Income & Education & Population \\
\hline \multirow{3}{*}{2000} & Income & 0.964 & & \\
\hline & Education & & 0.990 & \\
\hline & Population & & & 0.960 \\
\hline
\end{tabular}

